\title{
Metal-Organic Framework Encapsulated Whole-Cell Vaccines Enhance Humoral Immunity against Bacterial Infection
}

Michael A. Luzuriaga, ${ }^{1,6}$ Fabian C. Herbert, ${ }^{1,6}$ Olivia R. Brohlin, ${ }^{1}$ Jashkaran Gadhvi, ${ }^{2}$ Thomas Howlett, ${ }^{1}$ Arezoo Shahrivarkevishahi, ${ }^{1}$ Yalini H. Wijesundara, ${ }^{1}$ Sundharamani Venkitapathi, ${ }^{2}$ Kavya Veera, ${ }^{2}$ Ryanne Ehrman, ${ }^{1}$ Candace E. Benjamin, ${ }^{1}$ Sarah Popal, ${ }^{1}$ Michael D. Burton, ${ }^{3}$ Molly A. Ingersoll, ${ }^{5}$ Nicole J. De Nisco,, ${ }^{*}$ and Jeremiah J.

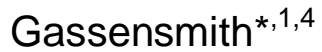

${ }^{1}$ Department of Chemistry and Biochemistry, ${ }^{2}$ Department of Biological Sciences, ${ }^{3}$ School of Brain and Behavioral Science, ${ }^{4}$ Department of Biomedical Engineering at The University of Texas at Dallas. 800 West Campbel Rd. Richardson, TX $75080{ }^{5}$ Department of Immunology, Institut Pasteur, Paris, France ${ }^{6}$ These authors contributed equally: Michael A. Luzuriaga, Fabian C. Herbert.

To whom correspondences should be addressed: Nicole.DeNisco@UTDallas.edu and Gassensmith@utdallas.edu

Abstract: The increasing rate of resistance of bacterial infection against antibiotics requires next generation approaches to fight potential pandemic spread. The development of vaccines against pathogenic bacteria has been difficult owing, in part, to the genetic diversity of bacteria. Hence, there are many potential target antigens and little a priori knowledge of which antigen/s will elicit protective immunity. The painstaking process of selecting appropriate antigens could be avoided with whole-cell bacteria; however, whole-cell formulations typically fail to produce long-term and durable immune responses. These complications are one reason why no vaccine against any type of pathogenic $E$. coli has been successfully clinically translated. As a proof of principle, we demonstrate a method to enhance the immunogenicity of a model pathogenic $E$. coli strain by forming a slow releasing depot. The E. coli strain CFT073 was biomimetically mineralized within a metal-organic framework (MOF). This process encapsulates the bacteria within 30 minutes in water and at ambient temperatures. Vaccination with this new formulation substantially enhances antibody production and results in significantly enhanced survival in a mouse model of bacteremia compared to standard inactivated formulations. 


\section{Introduction}

Pandemic and epidemic spread of bacterial infection was common until the advent of antibiotic therapies. Indeed, some of the largest epidemic death tolls are attributed to bacteria (e.g., Black Death, Cocoliztli epidemic, Russian typhus epidemic, the Asiatic cholera pandemic). Combined, just these four bacterial pandemics/epidemics resulted in more than 200 million deaths. ${ }^{1}$ While antibiotics have largely ended pandemic spread, it is clear that the evolution of antibiotic resistance has already begun to complicate the treatment of common bacterial infections like urinary tract infection (UTI). The primary causative agent of UTI is uropathogenic E. coli (UPEC) with approximately $80 \%$ of all community-acquired UTIs caused by UPEC. ${ }^{2-3}$ At least half of all women will develop a UTI in their lifetime and more than $40 \%$ of these individuals will experience recurrent infection. ${ }^{4-5}$ While men are less likely to develop UTI, their prognosis is often worse than women because the infection is associated with greater morbidity and mortality and typically requires longer courses of antibiotics to resolve the infection. ${ }^{6-9}$ The incidence and recurrent nature of UTI takes on more urgency given that $10-25 \%$ of uncomplicated UTI patient isolates are resistant to trimethoprim/sulfamethoxazole, a front-line antibiotic for treatment of UTI. ${ }^{10-11}$ When antibiotic treatment fails, bacteria persist in the bladder, increasing the cost of care and morbidity to the patient. ${ }^{12}$ Left untreated or undertreated, lower UTI can ascend to the kidneys and cross into the bloodstream, progressing to the more severe diseases of pyelonephritis and urosepsis, which have a global mortality rate of $40 \% .{ }^{13-14}$ Given the rise in antimicrobial resistance among UPEC strains and its potential lethality, efforts to develop non-antibiotic based therapies for UTI have increasingly focused on the development of prophylactic and therapeutic vaccines against UPEC. However, vaccine development against bacterial infection is challenging. In fact, no effective vaccines against any type of pathogenic $E$. coli have been clinically successful thus far. Therefore, new strategies to improve the efficacy and immunogenicity of bacterial vaccines must be developed.

Commonly, vaccines that target bacteria are created in three different ways. The first includes live-attenuated strains that are less pathogenic but capable of mutation and inducing strong immune reactions themselves. ${ }^{15-16} \mathrm{~A}$ second method is to use specific 
surface antigens found on bacteria in a subunit approach. However, subunit vaccines against $E$. coli strains tend to elicit poor $\mathrm{T}$ cell responses ${ }^{17-18}$ and have yet to translate into effective vaccines against UTI in humans. Further, a weak T-cell response will hinder antibody production and class switching, a significant problem when a humoral response is necessary to fight UTI. ${ }^{19-21}$ One reason for this may be that because the surface of $E$. coli is compositionally mosaic ${ }^{22}$ and antigens present within the outer membrane differ greatly between strains. A recent sequencing approach identified 230 potential protein surface antigens, of which only nine were ultimately protective in mice. ${ }^{23-24} A$ third approach is to create vaccines based on whole or lysed fractions of inactivated (dead) bacteria. This whole cell approach has produced more promising results in humans compared to purified subunit vaccines. ${ }^{25-26}$ Whole cell vaccines contain both conserved and strain-specific proteins and, as such, should provide the most comprehensive protection. However, whole-cell vaccines often fail to be protective in the long-term. ${ }^{27-31}$ The primary hurdle for the development of inactivated whole cell bacterial vaccines is the weak immune response they elicit because of their short halflife within the body, poor uptake by antigen presenting cells, and/or surface antigen degradation by harsh fixation methods. ${ }^{32-34}$

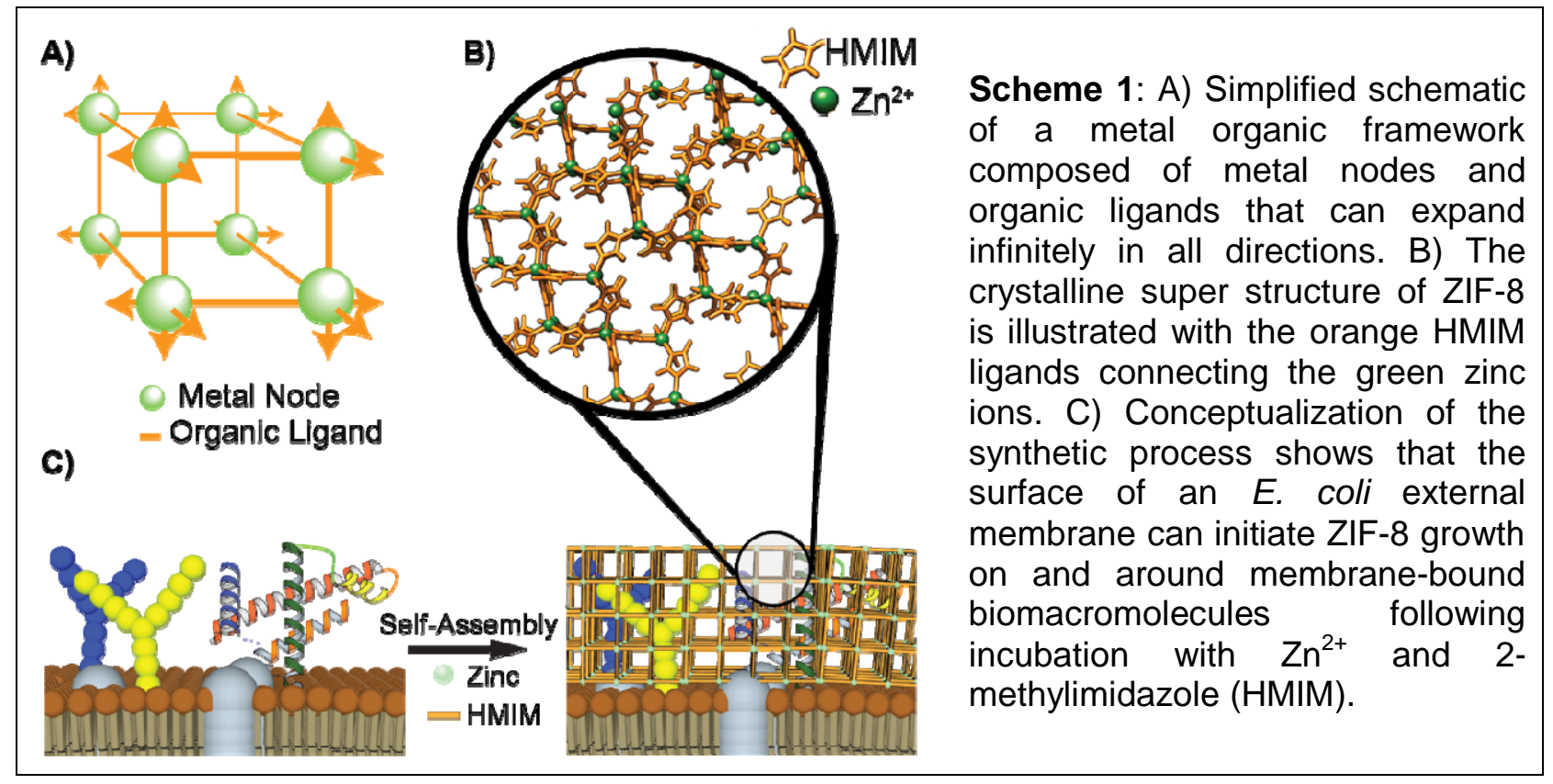


Methods to slow the release of antigens via an injected depot have profoundly positive effects on development of long-term antibody-based immunity by promoting germinal center (GC) formation in the draining lymph nodes. ${ }^{35-37}$ GCs are the primary site of $B$ cell maturation into antibody-producing plasma B cells. Whereas thermoplastics, ${ }^{38-43}$ liposomes, ${ }^{44-47}$ micelles, ${ }^{48-49}$ porous silicon, ${ }^{50-53}$ and polypeptides, ${ }^{54-55}$ have shown promise for small protein release and antigen delivery, ${ }^{56-60}$ it is not clear how these technologies will translate to whole-cell formulations. Methods to fully encapsulate "large cargo" such as whole bacterial cells are less explored. To address this challenge, we developed biomimetic encapsulation ${ }^{61-62}$ methods that fully encase individual bacteria inside a crystalline polymeric matrix called Zeolitic Imidazolate Frameworks (ZIFs - Scheme 1). ${ }^{63}$ We and others showed that mixing an array of biological molecules, including fluorescent proteins, ${ }^{64}$ insulin, ${ }^{65}$ proteins, ${ }^{66-67}$ IgG, ${ }^{68}$ viral nanoparticles, ${ }^{37,69-70}$ RNA, yeast, ${ }^{71-72}$ proteoliposomes, ${ }^{73}$ and Gram-positive and negative bacteria $^{74}$ within the ZIFs framework, incarcerates the target in a biodegradable matrix. ZIFs are a subclass of a broader family of solid-state single crystal metal organic frameworks (MOFs) characterized by interconnected organic ligands linked by metal nodes extending infinitely in all directions (Scheme 1A and 1B). We found that ZIF-8, a metal-organic framework composed of zinc ions interlinking 2-methylimidazole (HMIM) molecules in a repeating framework (Scheme 1B) selfassembles on protein surfaces through weak interactions between $\mathrm{Zn}^{2+}$ and peptide backbones. $^{70}$ The resulting ZIF-8 shell (Scheme 1C) has exceptional thermodynamic stability against high temperature, moisture, and organic solvents, but is kinetically labile in the presence of metal chelators such as EDTA and inorganic phosphates. These characteristics make ZIF-8 an ideal material for reversible immobilization. ${ }^{71,75-76}$ Here we report that, ZIF encapsulation preserves natively folded bacterial proteins better than traditional methods of preparing inactivated bacterial vaccines. Further, post-injection, ZIF-coated whole cell UPEC dissipate slowly at the injection site, induce a stronger humoral response compared to the controls, and provide superior protection against fatal septicemic UPEC infection in mice as compared to existing literature approaches. ${ }^{37}$ 


\section{Results and Discussion}

\section{Uropathogenic E. coli support growth of ZIF}

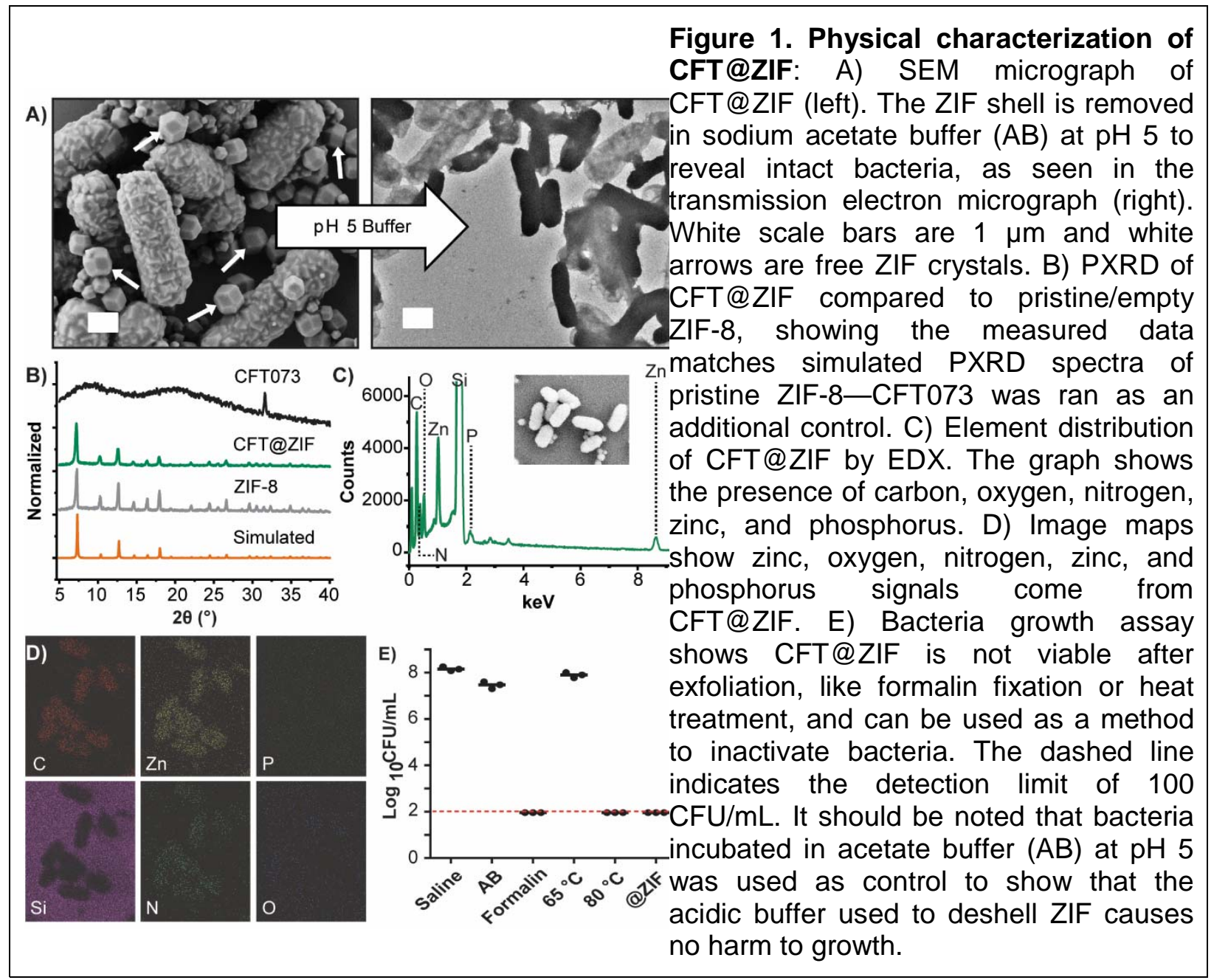

For this study, we used CFT073, a well-studied urosepsis strain of uropathogenic Escherichia coli (UPEC) frequently employed in the development of new vaccines, to allow us to benchmark our work against the literature. ${ }^{77}$ Gram-negative E. coli have an outer membrane containing embedded polysaccharides and proteins, ${ }^{20,23,78}$ which support ZIF-8 growth. We resuspended CFT073 in a saline solution containing 2methylimidazole (HMIM) and zinc acetate and after washing to remove excess zinc and HMIM, analyzed the resulting encapsulated bacteria, called CFT@ZIF, by scanning electron microscopy (SEM), powder X-ray diffraction (PXRD), and energy dispersive $X$ ray (EDX) spectroscopy. ZIF-8 growth occurred exclusively on the surface of the bacteria (Figure 1A). The PXRD of CFT@ZIF confirmed the shell was crystalline ZIF-8 
(Figure 1B) and EDX confirmed the presence of zinc and phosphorus, indicating both ZIF-8 and bacteria, respectively, were in the preparation (Figure 1C and D).

An initial challenge was the formation of free or empty ZIF-8 crystals. To find conditions that reduced the number of empty ZIF-8 particles (Figure 1A, white arrows), we tested a time course of incubation and a range of salinity in the encapsulation solution. We observed that an encapsulation time of 20 minutes and a final concentration of $100 \mathrm{mM}$ $\mathrm{NaCl}$ yielded crystal growth primarily on the bacteria (Fig. S1A-H). Using these parameters to generate CFT@ZIF, we then tested whether we could remove the shells from the encapsulated bacteria, in a process called exfoliation. We observed by transmission electron microscopy that the bacteria remained intact after dissolving the ZIF-8 shell in mildly acidic ( $\mathrm{pH} \mathrm{5)} \mathrm{sodium} \mathrm{acetate} \mathrm{buffer} \mathrm{and} \mathrm{no} \mathrm{obvious} \mathrm{debris} \mathrm{from}$ lysed bacteria were seen (Figure 1A). Next, we tested the stability of CFT@ZIF when lyophilized or kept in $0.9 \%$ saline solution. Both formulations were monitored over the course of 28 days by taking SEM images, which showed the composites had no obvious changes (Fig. S2A,B).

A challenge in whole-cell vaccine formulation is inactivating the bacteria with minimal damage to the surface epitopes, including delicate membrane-bound proteins and complex oligosaccharides. Biomimetic mineralization with ZIF is extremely gentle and we have previously shown that membrane bound proteins are not only preserved but protected by ZIF encapsulation in lipid nanoparticles. ${ }^{73}$ To show that our ZIF encapsulation approach preserves natively folded proteins better than traditional methods of inactivation, we conducted an agglutination assay using yeast. The fimbriae on the surface of CFT073 contain glycoproteins that are highly specific binders of sugar. When these proteins are damaged, they cannot bind sugar. Yeast, which have cellular surfaces rich in mannoprotein will crosslink bacteria forming aggregate clumps that can be directly imaged via microscopy as shown in the illustration in Fig. S2C. In our experiment, only untreated CFT073 and CFT@ZIF retained binding to the yeast, whereas CFT-Fixed and CFT-heat treated did not show any binding at the same concentration (Fig. S2D). These results support the that the growth of ZIF does not 
damage surface bound molecules. In addition, CFT@ZIF was left undisturbed in saline solution for 7 days and the agglutination was tested at day 0 and 7, which showed after 7 days it still retained binding to the yeast (Fig. S3). We next tested whether ZIF encapsulation inactivates CFT073. Following formation of the ZIF shell, immobilized CFT073 was incubated for $30 \mathrm{~min}$ at room temperature and exfoliated with $500 \mathrm{mM}$ sodium acetate buffer at pH 5. Unencapsulated CFT073 was inactivated using formalin or heating as described for other whole-cell bacterial vaccines, ${ }^{79-81}$ and bacterial viability was measured for each condition by colony forming unit (CFU) assay, and compared to untreated CFT073 incubated in $0.9 \%$ saline. Bacterial growth was observed for untreated CFT073 incubated in saline or in the sodium acetate buffer but not for bacteria that were formalin-fixed, heat-inactivated, or, importantly, exfoliated from the ZIF shell (Figure 1E). These results support that the ZIF-shell growth process itself inactivates bacteria, which is in line with previous observations that overexposure to zinc causes bacterial cell death. ${ }^{82-84}$

\section{Vaccination with CFT@ZIF induces a robust IgG response}

Having established that CFT073 was encapsulated, intact, and inactivated, we turned to vaccination studies. A humoral response depends on the activation of antigen-specific $B$ cells to differentiate into antibody-producing plasma B cells. ${ }^{85}$ We hypothesized that the ZIF shell would induce higher antibody titers because it not only avoids chemical alterations and thermal denaturation of surface proteins but also creates a slow releasing depot. We benchmarked our CFT@ZIF vaccine formulation against known methods to inactivate bacteria for whole-cell vaccine use: formalin fixation and heat treatment. $^{80,86-87}$ Formalin fixation induces chemical crosslinking of proteins to preserve their tertiary structure, resulting in bacterial cell death, whereas heat treatment kills bacteria through thermal stress. ${ }^{88}$ Here, formalin-fixed CFT073 are referred to as CFTfixed and heat treated CFT073 are denoted as CFT-Heat. We first compared the timeresolved fluorescence of smURFP-expressing CFT-Fixed against CFT@ZIF. The nearinfrared fluorescent protein smURFP was chosen for its durability and brightness and has been used to image nanomaterials in tissues as deep as the kidney in vivo. During heating, the smURFP expressed within CFT lost fluorescence, so CFT-heat was not 
used in the following experiments. Mice were injected with either saline, or the smURFP-expressing CFT-Fixed, or CFT@ZIF preparations subcutaneously and monitored over a period of 12 days until fluorescence levels returned to baseline (Figure 2A). Images collected by monitoring smURFP fluorescence during this period show that intact CFT@ZIF $\left(\mathrm{t}_{1 / 2}=106.4 \mathrm{~h}\right)$ remained at the injection site 4 days longer than CFT-Fixed $\left(\mathrm{t}_{1 / 2}=11.1 \mathrm{~h}\right.$, Figure 2B).

We next measured antibody titers in mice injected with saline, CFT-Fixed, CFT-Heat, or CFT@ZIF according to the vaccination and blood sampling schedule in Figure 2C. Serum from days 21 and 42 post-injection was serially diluted and the amount of antiCFT073 IgG produced was determined by enzyme-linked immunosorbent assay (ELISA). Mice immunized with CFT@ZIF produced the highest levels of anti-CFT073 IgG at day 21 and 42 compared to all other groups (Figure 2D). As expected, the thermally-inactivated CFT-Heat formulation induced the lowest antibody production, in line with the observation that high temperatures lead to thermal denaturation of proteinaceous and sugar-based epitopes. ${ }^{89}$ Following productive interaction with Th cells, activated $B$ cells undergo antibody class switching and change from producing IgM to IgG. IgG antibody responses can be further divided into subclasses, depending on the types of antigens they sense. We measured the different IgG subclasses by running the serum from day 21 on a multiplex assay, which showed an increase of $\lg \mathrm{G} 1$, IgG2a, and IgG2b for CFT@ZIF compared to CFT-Fixed (Fig. S4). B cells tend to switch to IgG2a when exposed to the inflammatory Th1 cytokine IFN-y or other proinflammatory agents such as LPS, whereas $\lg G 2 b$ and $\lg G 1$ are produced in the presence of the Th2 cytokine IL-4 and TGF- $\beta$. Thus, our results suggest a stronger T cell presence for CFT@ZIF compared to CFT-Fixed. As IL-6 promotes production of immunoglobulins by plasma cells, ${ }^{90}$ we diluted serum from day 14 and measured IL-6 production by ELISA. IL-6 levels were highest in CFT@ZIF, which correlated with enhanced production of antibodies in mice injected with this formulation (Figure 2E). The increase in CFT073-specific antibodies from mice injected with CFT@ZIF combined with the prolonged residency of CFT@ZIF at the injection site and the retained binding in the agglutination assay, supports the hypothesis that ZIF 
encapsulation helps prevent protein denaturation on the surface and provides a depot effect by prolonging the presence of CFT@ZIF in the tissue compared to unencapsulated bacteria.

ZIF-8 is generally non-toxic ${ }^{91-92}$ and, throughout our experiments, mice monitored daily showed no signs of pain or changes in behavior. At day 42, the mice were euthanized, and the spleen, liver, kidney, injection site tissue, lung, and heart were collected, fixed in formaldehyde, and stained with hematoxylin and eosin (H\&E) for pathological analysis. Organs displayed no signs of toxicity and H\&E-stained organ sections showed no
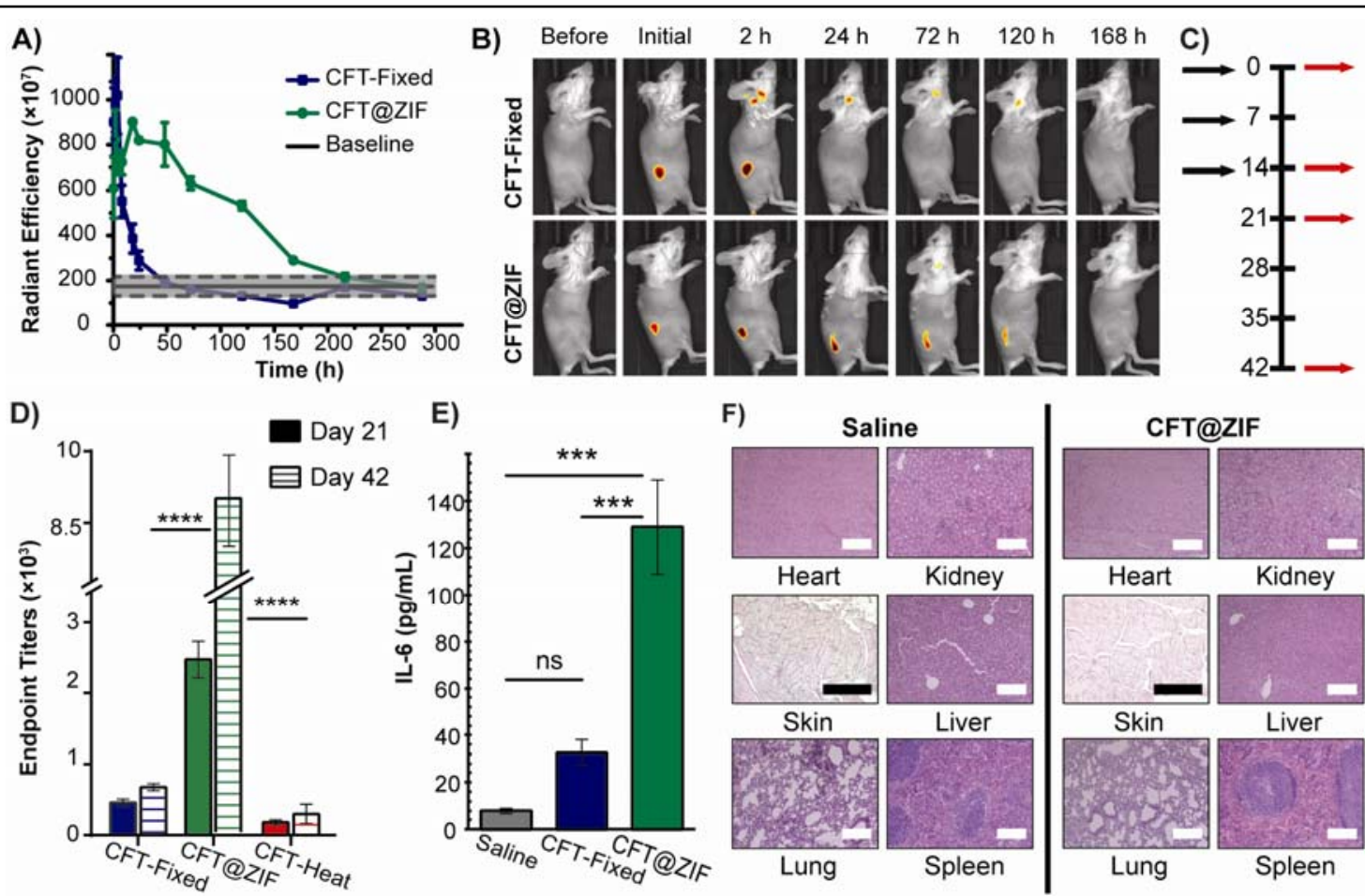

Figure 2. In vivo release: BALB/c Mice $(n=4)$ were injected with smURFP-expressing CFT073 that was inactivated with formalin (CFT-Fixed) or by encapsulation (CFT@ZIF). A) The graph shows fluorescence change at the site of injection over time. The baseline is the average fluorescence of four mice before and after injecting with saline. The dashed line represents the error of the baseline. B) Representative images of mice prior to injection with CFT-Fixed or CFT@ZIF and after injection were monitored over a course of 12 days. After injection, images were taken at 15, 30,60,120, 240, and $480 \mathrm{~min}$, then every $12 \mathrm{~h}$ for 12 days. C) Vaccination schedule for mice injected with either saline, CFT-Fixed, CFT@ZIF, or CFT-Heat. Black arrows are vaccinations and red arrows are blood draws. D) At day 21 and 42, blood was drawn and measured by ELISA to determine the antibody production. E) IL-6 in serum at day 14. F) H\&E staining of organs at day 42 . Error bars represent the mean $\pm S D$. Statistical significance was calculated using an ordinary one-way ANOVA with Tukey's multiple comparison post-test $\left({ }^{*} \mathrm{p}<\right.$ $\left.0.05,{ }^{* *} p<0.01,{ }^{* * *} p<0.0005,{ }^{* * *} p<0.0001\right)$. White scale bars are $100 \mu \mathrm{m}$ and black scale bars are $200 \mu \mathrm{m}$. 
abnormal lesions, aggregation, or change in tissue compared to mice injected with saline (Figure 2F) indicating the CFT@ZIF vaccine did not induce acute toxicity.

Cellular responses in the spleen and draining lymph node were characterized by flow cytometry on day 21 following the vaccination schedule illustrated in Figure $\mathbf{2 C}$. Notably, T-cell populations (CD3+, CD4+, and CD8+) were significantly elevated in the spleen of CFT@ZIF-treated mice compared to animals receiving the CFT-fixed formulation (Figure 3A) whereas T-cell responses against both formulations were comparable in the draining lymph node (Figure 3B). These data suggest that the CFT@ZIF formulation promotes a systemic immune response-as indicated by the more robust response in the spleen. Notably, B-cell numbers (CD19+) were significantly elevated in both the spleen and draining lymph node after CFT@ZIF vaccination, which was

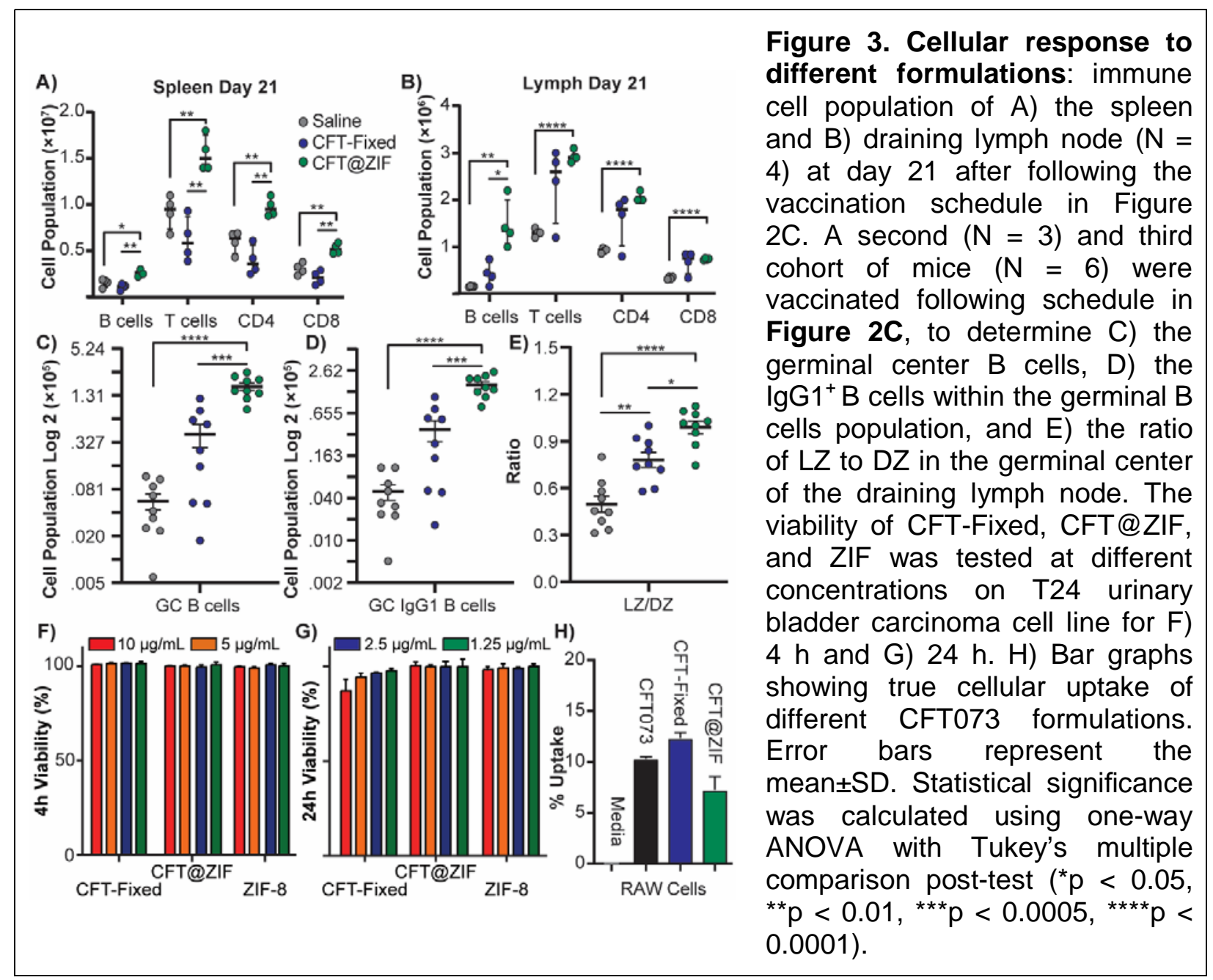


expected given the strong IgG response this formulation produced. We hypothesize that these results are a direct result of the slow-release depot effect, which we assess in the following section.

Antigen persistence via the depot effect is correlated with induction of a strong adaptive immune response. ${ }^{35,93}$ In a traditional bolus immunization, the half-life of the injected antigen is thought to be shorter than the required development time of germinal centers (GCs) in peripheral lymph tissue. ${ }^{35} \mathrm{GCs}$ are transient anatomical structures that form in lymphoid organs when early antigen-stimulated B-cells migrate and diversify into affinity B-cells and durable memory B-cells. The formation of GCs takes approximately a week and it is hypothesized a slow yet persistent release of antigens better matches the kinetics of GC B-cell development and ultimately the selection process for B-cells that produce high-affinity antibodies. ${ }^{94}$ In other words, by continuously supplying a source of antigens, GC B-cells have a longer opportunity to evolve the high affinity antibodies necessary to neutralize infections and if our depot mechanism is having an effect, we should see improved GC development. GC development can be assessed by measuring the amount of GC B-cells (GCBCs-CD19+, CD95+, and GL7+) in lymph tissue. To perform this analysis, a second cohort of mice were vaccinated following the schedule in Figure $\mathbf{2 C}$ and on day 21, the draining lymph nodes were removed. We saw a larger population of GCBCs in the draining lymph nodes of mice vaccinated with CFT@ZIF compared to fixed CFT (Figure 3C) and a higher frequency of class switched GCBCs $\left(\operatorname{lgG} 1^{+}\right)$(Figure 3D), which is strongly correlated to a protective antibody response. GCs develop into two different microenvironments-a dark zone (DZ), where GCBCs undergo somatic hypermutation and create receptors of varying affinity against an antigen, and a light zone (LZ), where only antigen-specific high-affinity receptor Bcells are selectively differentiated into memory or plasma B cells. ${ }^{95}$ Consequently, LZ growth indicates an increase in affinity selection and production of B-cells that produce high affinity antibodies. When we analyzed the draining lymph nodes by flow cytometry, we found a shift in the light zone to dark zone (LZ/DZ) ratio for mice vaccinated with CFT@ZIF (Figure 3E) compared to the formalin inactivated formulations. Taken together, we postulate that a likely reason we see such a strong B cell response from CFT@ZIF is from the antigen depot effect. 
A second mechanistic explanation for the higher antibody titers may be increased uptake by professional phagocytes. Prior literature has suggested that ZIF-8 improves cellular uptake. ${ }^{96-99}$ ZIF-8 dissolves in the acidic compartments of phagosomes, endosomes, and lysosomes, which would free surface epitopes in a manner similar to acidic exfoliation buffer. First, we tested the toxicity of CFT@ZIF by conducting an LDH assay at $4 \mathrm{~h}$ and $24 \mathrm{~h}$ at 1.25, 2.5, 5, $10 \mu \mathrm{g} / \mathrm{mL}$ with T24 human urinary bladder carcinoma cell line and RAW 264.7 macrophages (Figure 3F,G and Fig. S5A,B), which showed no toxicity at all concentration tested and is in line with other biocompatibility studies using ZIF ${ }^{91-92,96}$ _CFT-Fixed and ZIF were used as controls. Next, we performed ZIF-8 shell growth on smURFP-expressing CFT073. CFT073, CFT-Fixed, and CFT@ZIF were incubated for four hours with RAW 264.7 macrophages to investigate if our ZIF encapsulation improved uptake. Confocal microscopy images showed that CFT@ZIF was taken up more readily by the RAW 264.7 macrophages (Fig. S5C) and flow cytometry analyses found a four-fold increase in uptake of CFT@ZIF over untreated CFT073 and CFT-fixed (Fig. S5D). While this initially appeared to validate prior literature observation, upon closer inspection, we found a significant amount of the CFT@ZIF had adhered to the surface of the macrophages. To remove this surface-attached ZIF-encased bacteria, we included three rapid washes with a low $\mathrm{pH}$ buffer-a method developed originally to strip $\lg \mathrm{E}$ antibodies from cell surfaces. ${ }^{100-}$ 102 Another LDH assay was conducted to ensure that the low $\mathrm{pH}$ wash would not be toxic to the RAW 264.7 macrophages, which again showed the treatment did not kill the cells (Fig. S5E). The low $\mathrm{pH}$ wash completely dislodged the ZIF bound to the macrophage surface as confocal micrographs show no CFT@ZIF on the surface of the acid-washed macrophages (Fig. S5F). Following our acid washing step, flow cytometry revealed that the uptake of CFT@ZIF was lower than the other washed inactivated samples (Figure $\mathbf{3 H}$ ), further suggesting that a depot effect is likely the principal driver of the increased immune activation.

\section{Vaccination with CFT@ZIF protects mice from lethal sepsis challenge}

Activation of a cell-mediated adaptive immune response is a vital aspect of vaccine development to promote long-term memory. ${ }^{103-104}$ To determine whether CFT@ZIF 
bioRxiv preprint doi: https://doi.org/10.1101/2020.06.14.148452; this version posted July 29, 2021. The copyright holder for this preprint (which was not certified by peer review) is the author/funder, who has granted bioRxiv a license to display the preprint in perpetuity. It is made available under aCC-BY-NC-ND 4.0 International license.

promotes a cell-mediated adaptive immune response, we measured TNF-a, IL-2 and 
IFN $\gamma$ serum levels. TNF- $\alpha$ is an immunostimulatory cytokine mainly produced by macrophages and $T_{h} 1$ (Type $1 \mathrm{~T}$ helper) $C D 4^{+} T$ cells while IL-2 is a cytokine produced mainly by CD4+ T cells and activated CD8+ $T$ cells to promote $T$ cell survival and $T$ cell differentiation. IFN- $\gamma$ is a cytokine produced mainly by $T_{h} 1 T$ cells and dendritic cells promoting a cell-mediated response by stimulating cytotoxic T lymphocytes. ${ }^{105-106}$ In addition, we measured IL-4, a cytokine produced in part by $\mathrm{T}_{\mathrm{h}} 2$ (Type $2 \mathrm{~T}$ helper) CD4+ T cells, which induces an antibody-mediated response and IL-17, a cytokine that plays a protective role against $E$. coli infection. ${ }^{107-109}$ We employed the vaccination schedule
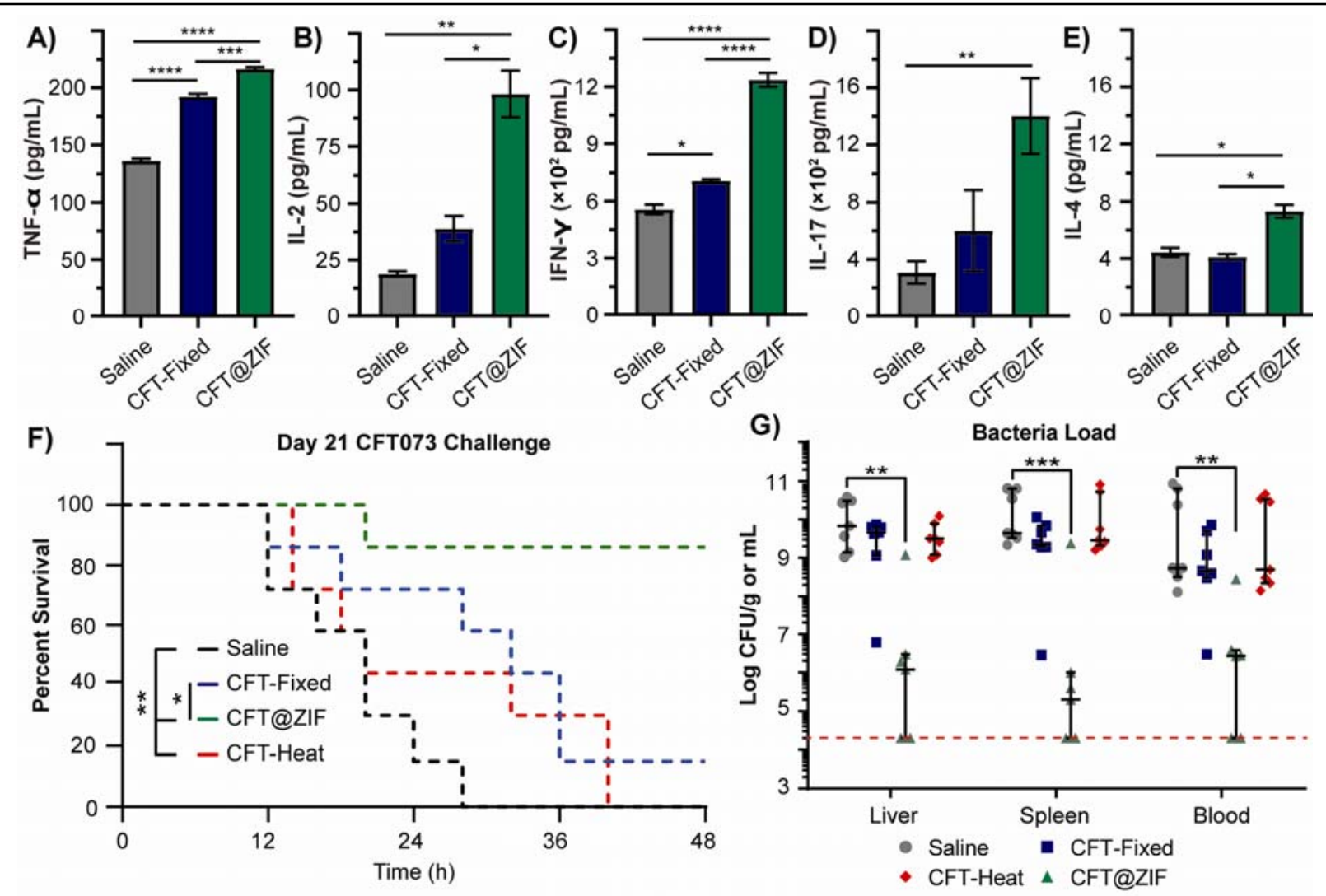

Figure 4. Survival Study: Mice $(n=4)$ were injected with CFT073 that was inactivated with formalin (CFT-Fixed) or by encapsulation (CFT@ZIF). At Day 42, splenocytes were collected from immunized mice and incubated with $10 \mu \mathrm{g} / \mathrm{mL}$ of CFT073 for $48 \mathrm{~h}$. After $48 \mathrm{~h}$, the supernatant was tested for A) TNF- $\alpha$, B) IL-2, C) IFN- $\gamma$, D) IL-17, and E) IL-4. Two separate cohorts of mice $(n=3$ and $n=4)$ following the vaccination schedule in Figure $2 C$ were injected interperitoneally with a lethal dose of CFT073 at day 21 and monitored for $48 \mathrm{~h}$. F) Survival for each group over the course of $48 \mathrm{~h}$. G) Bacterial loads in the liver, spleen, and blood at the endpoint of the survival study. Error bars represent the mean $\pm S D$. Statistical significance was calculated using an ordinary one-way ANOVA with Tukey's multiple comparison posttest $\left({ }^{*} p<0.05,{ }^{* *} p<0.01,{ }^{* * *} p<0.0005,{ }^{* * * *} p<0.0001\right)$. 
depicted in Figure 2C, and on day 42, re-stimulated splenocytes with CFT073 for each group. We measured TNF-a, IL-2, IFN- $\gamma$, IL-17, and IL-4 cytokine (Figure 4A-E) levels by ELISA and observed that mice immunized with CFT@ZIF had higher levels of all cytokines compared to CFT-Fixed treated mice following re-stimulation. In particular, mean titers of IL-2 and IL-17 were more than 2-fold higher in splenocytes derived from CFT@ZIF compared to CFT-Fixed vaccinated mice (Figure 4B,D). Titers of TNF-a, IFN-y, and IL-4 were 1.4-fold, 2.0-fold and 2.0-fold higher, respectively, in splenocytes derived from CFT@ZIF vaccinated mice compared to CFT-Fixed vaccinated mice (Figure 4A, C,E). Taken together, our data demonstrate that CFT@ZIF induces a more robust cytokine response that is indicative of enhanced T cell activation.

Mice vaccinated with CFT@ZIF had increased antibody production and increased expression of key cytokines at day 42 compared to other CFT formulations (Figure 4AE). To determine whether these responses would be protective, we used a previously described urosepsis model. ${ }^{12,} 110$ Two survival studies performed with separate preparations of vaccine composites were conducted. We vaccinated as shown in Figure 2C with either saline, CFT-Fixed, CFT-Heat, or CFT@ZIF. On day 21, we administered a lethal dose ${ }^{110}$ of CFT073 intraperitoneally and mice were monitored over the course of 48 hours and euthanized when they became moribund, defined by lack of movement for over 15 minutes, shaking in place, and a decrease of body temperature or the 48-hour endpoint was reached. The Kaplan Meier analysis reported in Figure 4F shows that CFT@ZIF-vaccinated mice had improved survival compared to all other groups. The median survival time for sham treated (saline) controls was 16 hours compared to 20 hours for mice vaccinated with CFT-Heat and 32 hours for mice vaccinated with CFT-fixed. Strikingly, 85.7\% (6/7) of the CFT@ZIF-vaccinated mice survived until the 48 hour endpoint with no visible signs of disease. After euthanasia, blood, spleens, and livers were collected, homogenized, and CFUs were enumerated (Figure 4G). Average bacterial load in the blood $\left(2.7 \times 10^{6}\right.$ CFUs), spleens $\left(1.2 \times 10^{6}\right.$ CFUs), and livers $\left(2.0 \times 10^{5}\right.$ CFUs) of CFT@ZIF-vaccinated mice were three-to-four orders of magnitude lower $\left(\sim 10^{9}-10^{8} \mathrm{CFUs}\right)$ than all the other groups with three CFT@ZIF animals having no detectable bacterial burden in the blood, spleen, or liver. It 
is noteworthy that this reduction in bacterial load and survival exceeds the efficacy of published subunit vaccine strategies for CFT073 sepsis. ${ }^{12}$ We hypothesize that the lower bacterial load and greater survival of the CFT073@ZIF-vaccinated mice may be attributed to the 5-fold higher anti-CFT073 IgG titers that CFT@ZIF promotes over the more traditional CFT-Fixed formulation (Figure 2D).

\section{Conclusion}

In this work, we demonstrated that ZIF-8 effectively inactivated a urosepsis strain of UPEC, creating a persistent vaccine depot that considerably outperformed current whole cell inactivation methods in survival following lethal challenge in a sepsis model, B-cell, and T-cell activation. This method of inactivation avoids the use of toxic formaldehyde, is faster, and yields consistent superior results. Only CFT@ZIFvaccinated mice survived a lethal dose of CFT073, which we hypothesize may be due to the five-fold increase in serum levels of $\lg G$ that arises from our depot approach, as evidenced by greater GC formation in draining lymph tissue. Finally, the biomimetic growth strategy that we employed here is likely generalizable across different organisms, presenting an opportunity for a generalizable approach toward whole-cell bacterial vaccine formulation. Formulation of the inactivated bacteria does not use dangerous or toxic compounds, involves the mixture of only three components, and the total reaction time is under 30 minutes. We and others have shown, moiety encapsulation with ZIF is a straightforward method that can easily be scaled up. Further, increasing reaction volumes does not alter the morphology of the as obtained materials as shown by PXRD (Powder X Ray diffraction) and SEM. ${ }^{74,111}$ Our ecologically friendly and low-cost approach has shown that it can produce protective effects that exceed published subunit strategies making it an ideal platform for rapid vaccine production from patientderived bacterial strains. This opens potential opportunities to produce patient-specific prophylactic and therapeutic vaccine formulations for those suffering from recurrent UTI or at increased risk for complicated UTI in a personalized medicine approach.

\section{Methods}

Materials 
Acetic acid, acetic anhydride, anti-mouse IgG (whole molecule)-alkaline phosphatase produced in goat, arabinose, bovine serum albumin, diethanolamine, magnesium chloride, $\beta$-mercatoethanol, methanol, 2-methylimidazole, paraformaldehyde, $p$-nitro phenyl phosphate, potassium hydroxide, potassium phosphate dibasic, potassium phosphate monobasic, poly(vinylpyrrolidone) 40k (PVP 40k), 2-propanol, sodium azide, sodium bicarbonate, sodium carbonate, sodium chloride, sodium hydroxide, sodium phosphate dibasic, sodium phosphate monobasic, Tween-20, and zinc acetate dihydrate were purchased from Sigma-Aldrich (St. Louis, MO, USA), Thermo Fisher Scientific (Waltham,

MA, USA), Chem-Impex Int'l (Wood Dale, IL, USA), or VWR (Radnor, PA, USA), and used without further modification. Anti-rat CD3-APC, anti-mouse CD4-PE/Cy7, anti-rat CD8a-APC/Cy7, anti-mouse CD44-FITC, anti-rat CD62L-BV605, ELISA MAX'M Standard Set Mouse IL-6, TNF-a, and IFN- $\gamma$ were from Biolegend. LDH-Cytox ${ }^{\text {TM }}$ Assay Kit was purchased from Biolegend (Cat. No. 426401). The LEGENDplex ${ }^{\mathrm{TM}}$ Mouse Immunoglobulin Isotyping Panel (6-plex) was bought from BioLegend. Ultrapure water was obtained from an ELGA PURELAB flex 2 system with resistivity measured to at least $18.2 \mathrm{M} \Omega-\mathrm{cm}$.

\section{Bacterial Studies}

Bacterial strains and growth conditions

CFT073 was obtained from ATCC and grown in Luria Bertani (LB) medium at $37^{\circ} \mathrm{C}$ for all experiments. pLenti-smURFP was a gift from Erik Rodriguez \& Roger Tsien and was transformed into CFT073 electrocompetent cells as described: $50 \mu \mathrm{L}$ of electrocompetent CFT073 were thawed on ice, then mixed with $100 \mathrm{ng}$ of pLentismURFP and incubated on ice for 20 minutes. The mixture was transferred to an electroporation cuvette and electroporated at $1.8 \mathrm{kVs}$. $500 \mu \mathrm{L}$ of SOB media was immediately added and the cells recovered for 60 minutes at $37^{\circ} \mathrm{C}$. Transformants were selected on LB agar plates supplemented with $100 \mu \mathrm{g} / \mathrm{mL}$ ampicillin. For encapsulation experiments, CFT073-smURFP was grown to an $\mathrm{OD}_{600}$ of $0.9-1$ and $10 \mathrm{mg} / \mathrm{mL}$ arabinose was added to induce smURFP expression. After 4 hours, cells were harvested by centrifugation at $2,000 \times \mathrm{g}$ for $10 \mathrm{~min}$ and washed three times with $0.9 \%$ 
saline. Pellets were weighed to ensure exactly $40 \mathrm{mg} / \mathrm{mL}$ of CFT073 would be the stock solution for all studies described. CFT@ZIF was prepared by adding $1 \mathrm{mg}$ of CFT073 from the stock solution and $500 \mathrm{uL}$ of $1600 \mathrm{mM}$ 2-methylimidazole (HMIM) into a $1.5 \mathrm{~mL}$ microcentrifuge tube, followed by the addition of $500 \mu \mathrm{L}$ of $20 \mathrm{mM}$ zinc acetate dihydrate (ZnOAC). The tube was capped, swirled for $20 \mathrm{~s}$, and left to incubate at RT for $20 \mathrm{~min}$. HMIM and ZnOAC solution were made using $100 \mathrm{mM} \mathrm{NaCl}$ solution to keep bacteria near isotonic conditions. The solution became cloudy after a few minutes and remained colloidal throughout the incubated timeframe. Longer time frames than 20 minutes led to free ZIF-8 as seen in Extended Data Fig. 2. After $20 \mathrm{~min}$, the solution was centrifuged at $4500 \times g$ for $10 \mathrm{~min}$ at $4^{\circ} \mathrm{C}$. The supernatant was discarded, and the pellet was washed with ultrapure water twice. The final CFT@ZIF powder was either dried to characterize the sample or placed into $0.9 \%$ saline for in vitro and in vivo studies.

\section{Bactericidal Assay}

In a $1.5 \mathrm{~mL}$ microcentrifuge tube, either $0.9 \%$ saline or $500 \mathrm{mM}$ acetic/acetate buffer $\mathrm{pH}$ 5 (Acetate buffer) at a volume of $975 \mu \mathrm{L}$ was added to each tube. $25 \mu \mathrm{L}$ of CFT073 or dried CFT@ZIF was added to each tube to obtain a $1 \mathrm{mg} / \mathrm{mL}$ concentration of bacteria. Acetate buffer can exfoliate the ZIF shell and was used as a control to show that untreated CFT073 will continue to grow when incubated for the same amount of time it takes to exfoliate CFT@ZIF.CFT@ZIF must be incubated for $30 \mathrm{~min}$ to be fully exfoliated. The untreated CFT073 or CFT@ZIF was suspended in 0.9\% saline and left at $80{ }^{\circ} \mathrm{C}$ for 15 minutes. As previously stated, untreated CFT073 was exposed to identical stress conditions, dilutions, and incubation in $500 \mathrm{mM}$ acetic/acetate buffer $\mathrm{pH}$ as CFT@ZIF biocomposites. Formalin-fixed CFT073 (CFT-Fixed) was made by placing $1 \mathrm{mg}$ in $5 \%$ formalin to a final volume of $1 \mathrm{~mL}$ and incubating overnight. CFT-Fixed was then centrifuged at $4,000 \times g$ and washed with $0.9 \%$ saline, twice. Each of the tested conditions was serially diluted (10-2 to 10-9) and spotted on an LB agar plates to determine the colony-forming unit (CFU) titers formed after $12 \mathrm{~h}$, individually. All experiments included $n=3$ per sample tested. 
Bacterial strains at an $\mathrm{OD}_{600}$ of 0.5 grown in Luria Bertani (LB) medium overnight at $37^{\circ} \mathrm{C}$ in static conditions. Saccharomyces cerevisiae (yeast) at an $\mathrm{OD}_{600}$ of 0.5 was grown in yeast extract-peptone-dextrose (YPD) medium overnight at $27^{\circ} \mathrm{C}$ in an incubator at $225 \mathrm{rpm}$. Bacterial and yeast cultures were centrifuged at 2655 rcf for 5 minutes at room temperature and resuspended in $1000 \mu \mathrm{l}$ of PBS..The OD of a 1 $\mathrm{mg} / \mathrm{mL}$ stock of CFT073 was measured and used to adjust the concentration of the stock to a desired OD. $800 \mathrm{mM}$ HMIM and $10 \mathrm{mM}$ ZnOAC representing the final concentration in the CFT@ZIF reaction were prepared as samples. CFT-Heat was prepared by adding CFT073 to $100 \mathrm{mM}$ saline for an OD 0.20 and final volume of $1 \mathrm{~mL}$ and submerged in an $80{ }^{\circ} \mathrm{C}$ water bath for $15 \mathrm{~min}$. ZIF-8 was prepared in the same manner as CFT@ZIF but without the addition of CFT073. CFT@ZIF was prepared as mentioned above but CFT073 at an OD of 0.20 was added after HMIM and before $\mathrm{ZnOAC}$. These were washed twice at 4,300 $\times g$ and resuspended in $100 \mathrm{mM}$ saline to 1 $\mathrm{mL}$. CFT-Fixed was prepared as previously stated but also at an OD: 0.20. Each sample was added to yeast at a 2:1 ratio on a glass microscope slide and mixed by shaking for $2 \mathrm{~min}$. Microscope images were taken at $10 \times$ magnification at $10 \mathrm{~min}$ and $20 \mathrm{~min}$.

\section{Lactate dehydrogenase (LDH) Cytotoxicity Assay}

Procedure was performed as recommended by vendor. Briefly, T24 and RAW 264.7 cells were seeded in a 96 well plate $\left(100 \mathrm{uL} /\right.$ well) at a concentration of $1 \times 10^{\wedge} 6 \mathrm{cells} / \mathrm{mL}$ and incubated overnight in a $37^{\circ} \mathrm{C} \mathrm{CO}_{2}$ incubator. The next day the media was removed and replaced with clean media containing the designated CFT samples at the designated concentrations (100 uL/well) in triplicate and incubated for $4 \mathrm{~h}$ at $37^{\circ} \mathrm{C}$ in a $\mathrm{CO}_{2}$ incubator. After $4 \mathrm{~h} 10 \mathrm{uL}$ of lysis buffer was added to the negative control wells and incubated at $37^{\circ} \mathrm{C}$ in a $\mathrm{CO}_{2}$ incubator for 30 mins. Next $100 \mathrm{uL}$ of working solution was added to each well and incubated in the dark at room temperature for 30 mins. Lastly, $50 \mathrm{uL}$ of stop solution was added to all wells and the plate was read at $490 \mathrm{~nm}$.

Macrophage Uptake by Flow Cytometry 
RAW Macrophage 264.7 cells were cultured in Dulbecco's Modified Eagle Medium supplemented with $10 \%$ FBEssence and $1 \%$ penicillin-streptomycin $(50 \mu \mathrm{g} / \mathrm{mL})$. Cells were seeded at $\sim 10^{5}$ cells $/ \mathrm{mL}$ in a 6 well plate one day prior to testing. The cells were incubated with $25 \mu \mathrm{g} / \mathrm{mL}$ of indicated samples for 4 hours. The cells were washed $3 \times$ with low $\mathrm{pH}$ buffer $(0.5 \%$ acetic acid, $0.5 \mathrm{M} \mathrm{NaCl}, \mathrm{pH} 3), 3 \times$ with $1 \times \mathrm{PBS}$, resuspended in $1 \mathrm{~mL}$ of $1 \times$ PBS, and transferred to a $5 \mathrm{~mL}$ sterile polystyrene tube. $\sim 10,000$ gated events per sample were collected using a BD LSRFortessa ${ }^{\text {TM }}$ flow cytometer. Raw data were processed and analyzed using FlowJo® software Version 10.6.1. Histogram overlays were normalized to mode to compare samples that varied in number of recorded events.

\section{Macrophage Uptake by Fixed Cell Imaging}

RAW Macrophage 264.7 cells were cultured in Dulbecco's Modified Eagle Medium supplemented with $10 \%$ FBEssence and $1 \%$ penicillin-streptomycin $(50 \mu \mathrm{g} / \mathrm{mL})$. Cells were seeded at $\sim 10^{5}$ cells $/ \mathrm{mL}$ in a 6 well plate one day prior to testing. The cells were incubated with $25 \mu \mathrm{g} / \mathrm{mL}$ of indicated samples for 4 hours. The cells were washed $3 \times$ with low $\mathrm{pH}$ buffer $(0.5 \%$ acetic acid, $0.5 \mathrm{M} \mathrm{NaCl}, \mathrm{pH} 3), 3 \times$ with $1 \times \mathrm{PBS}$, fixed with $4 \%$ paraformaldehyde, stained with $300 \mathrm{nM}$ DAPI and $5 \mu \mathrm{g} / \mathrm{mL}$ WGA-TRITC, washed $3 \times$ with $1 \times$ PBS, washed $3 \times$ with autoclaved MilliQ water, and mounted on glass slides using Fluoroshield histology mounting media. Fixed cell imaging was performed with an Olympus FV3000 RS Confocal microscope. Raw images were processed using ImageJ software.

\section{Antigen stimulation of splenic T lymphocytes}

Mice were injected on days $0,7,14$ and splenocytes were isolated from immunized mice 7 days after the third immunization. The cells were stained with anti-CD3-PacBlue, anti-CD4-PE/Cy7, anti-CD8a-FITC, and anti-B220-Alexa700 and analyzed by flow cytometry (gating strategy illustrated in Fig S5A). Another set of mice were vaccinated according to Figure $\mathbf{2 C}$, at day 42 the spleens were collected and homogenized into 
single cell suspension. The cells were seeded at $\sim 1.0 \times 10^{6}$ cells per well in a 24 well plate and supplemented with RPMI 1640 medium, 10 \% FBEssence, 1 \% penicillinstreptomycin, and 50 $\mathrm{mm}$-mercaptoethanol. Cells were re-stimulated with $10 \mathrm{ug}$ of untreated CFT073 (10 $\mathrm{gg} / \mathrm{mL})$ for 48 hours. The supernatant was tested for cytokine production by enzyme-linked immunosorbent assay (ELISA).

\section{Immunophenotyping of the draining lymph node}

Mice were injected on days 0, 7, 14 and the draining lymph node was isolated from immunized mice 7 days after the third immunization. Briefly, the cells were homogenized into single cell suspension and stained at $\sim 1.0 \times 10^{6}$ cells with antiCD19-Alexa700, anti-CD95-APC, anti-GL7-Alexa488, anti-CD86-BV785, anti-CD184BV421, and anti-lgG1+-PE and analyzed by flow cytometry (gating strategy illustrated in Fig. S5B). B cells in the light zone express CD86 ${ }^{\text {hi }}$ and B cells in the dark zone express CD86 ${ }^{\text {low }}$.

\section{Antibody and cytokine ELISA}

CFT073-specific antibody production was determined by following a previously published method. ${ }^{81}$ Briefly, lyophilized CFT073 was resuspended in $0.05 \mathrm{M} \mathrm{pH} \mathrm{9.6}$ sodium carbonate/bicarbonate buffer to a concentration of $0.31 \mathrm{mg} / \mathrm{mL}, 150 \mu \mathrm{L}$ was added to each well, and was incubated at $37^{\circ} \mathrm{C}$ for $90 \mathrm{~min}$. The plate was emptied and washed 4 times with wash buffer. $200 \mu \mathrm{L}$ of blocking buffer was added to each well and was incubated at $37^{\circ} \mathrm{C}$ for $45 \mathrm{~min}$. The plate was emptied and washed 4 times with wash buffer. Mouse serum was serially diluted 7 times starting at a $200 \times$ dilution using $1 \times$ PBS at ph $7.4,150 \mu \mathrm{L}$ added to each well, and incubated at $37^{\circ} \mathrm{C}$ for $90 \mathrm{~min}$. The plate was emptied and washed 4 times with wash buffer. Alkaline phosphataseconjugated goat anti-mouse IgG in conjugate buffer was added $150 \mu \mathrm{L}$ per well and incubated at $37^{\circ} \mathrm{C}$ for $90 \mathrm{~min}$. The plate was emptied and washed 4 times with wash buffer. $1 \mathrm{mg} / \mathrm{mL}$ p-nitrophenylphosphate in substrate buffer was added at $150 \mu \mathrm{L}$ per well and the plate developed for $15 \mathrm{~min}$ at R.T. The plate was read at $405 \mathrm{~nm}$ and the absorbance values of the buffer blank wells averaged and subtracted from the entire plate. The blank-subtracted values of each mouse group were reported as the average 
\pm standard deviation for each dilution. The levels of TNF-a, IL-17, IL-4, IL-2, and IFN- $\square$ were determined by ELISA following protocols recommended by the manufacturer.

\section{Quantitation of Immunoglobulin Isotyping:}

Assay was performed following guidelines provided by the vendor. Further, assay was used to quantify 6 immunoglobulins from frozen serum samples. Briefly, $2 \mu \mathrm{L}$ serum was diluted to 50,000 times using assay buffer and IgG1, IgG2a, IgG2b, IgG3, IgA and IgM levels were measured according to the manufacturer's protocol. Streptavidin phycoerythrin (SA-PE) intensity was analyzed by a FACS LSR Fortessa instrument (Becton Dickinson), and each analyte was quantified relative to the kit standard curve using LEGENDplex software, version 8.0.

\section{Animal Studies}

\section{Ethics Statement}

Female BALB/c were obtained from Charles River Lab (Wilmington, Ma). All animal studies were done in accordance with protocol \#19-06 approved by the University of Texas at Dallas Institutional Animal Care and Use Committee (IACUC).

\section{Vaccinations}

20 BALB/c mice were divided into five groups $(n=4)$ and injected with saline, formalin CFT-Fixed, CFT@ZIF, CFT-Heat, or CFT@ZIF-Heat suspended in saline. Heat-treated samples were placed in $80^{\circ} \mathrm{C}$ water for 15 minutes. CFT073 solutions were prepared such that $100 \mu \mathrm{L}$ delivered $10 \mu \mathrm{g}$ of CFT073. Doses of $100 \mu \mathrm{L}$ of saline, CFT-Fixed, CFT@ZIF, CFT-Heat or CFT@ZIF-Heat were administered subcutaneously on day 0,7, and 14, and blood was withdrawn submandibularly on day $0,14,21$, and 42 . The blood was centrifuged to remove cells, and the anti-CFT073 IgG content of the resultant serum was determined by ELISA as described above. At the end of the study, the mice were sacrificed for histological analysis on the spleen, liver, kidney, lung, heart, and the skin at the administration site. The mice were sacrificed by carbon dioxide asphyxiation, the organs collected, and fixed in $4 \%$ formaldehyde overnight. The fixed organs were 
moved to a $70 \%$ ethanol solution and processed with an ASP300 S tissue processor (Leica Biosystems, Buffalo Grove, IL) for dehydration into paraffin. The organs were then embedded into paraffin wax using a HistoCore Arcadia $\mathrm{C}$ and $\mathrm{H}$ paraffin embedding station (Leica Biosystems, Buffalo Grove, IL). Each organ was sliced into 4 um sheets using a RM2235 manual microtome (Leica Biosystems, Buffalo Grove, IL) and imaged with a DMi1 optical microscope (Leica Biosystems, Buffalo Grove, IL) at $40 \times$ magnification.

\section{Body Clearance}

$10 \mathrm{BALB} / \mathrm{c}$ mice were fed a non-fluorescent diet and shaved 12 hours before imaging to reduce autofluorescence from the hair. The mice were anesthetized with isoflurane and injected with $100 \mu \mathrm{L}$ saline $(\mathrm{n}=4)$, CFT(smURFP)-Fixed, or CFT(smURFP)@ZIF. The CFT073 containing solutions were prepared such that $100 \mu \mathrm{L}$ delivered $10 \mu \mathrm{g}$ of CFT073. A series of time points were taken after injection at $30 \mathrm{~min}, 2 \mathrm{~h}, 4 \mathrm{~h}, 8 \mathrm{~h}, 18 \mathrm{~h}$, 24 h, 48 h, 72 h, 120 h, 168 h, 216 h, and 288 h. The fluorescence returned to the levels of saline at 48 hours for CFT-Fixed and 216 h for CFT@ZIF.

\section{CFT073 Sepsis Challenge}

As ours is a developing technology with many unknowns, we expect that for the CFT@ZIF there will initially be larger variances in humoral response which we expect to be around $20 \%$. To detect at least a $20 \%$ difference in the protein expression changes with a power $=0.8$ and a significance level of 0.05 , a sample size of at least 6 mice will be necessary. 20 BALB/c mice were divided into five groups (Two cohorts, $n=3$ and $n=4$ ) and injected with saline, formalin CFT-Fixed, CFT@ZIF, CFT-Heat, or CFT@ZIF-Heat suspended in saline. Heat treated samples were placed in $80^{\circ} \mathrm{C}$ water for 15 minutes. CFT073 solutions were prepared such that $100 \mu \mathrm{L}$ of $0.9 \%$ saline delivered $10 \mu \mathrm{g}$ of CFT073. Doses of $100 \mu \mathrm{L}$ of saline, CFT-Fixed, CFT@ZIF, CFT-Heat or CFT@ZIFHeat were administered subcutaneously on day 0,7 , and 14 . On day 21 , all mice were injected interperitoneally with a lethal dose of $3.6 \times 10^{8}$ CFU of CFT073 per mouse and monitored for $48 \mathrm{~h}$. All mice were euthanized when they became moribund, which is defined by lack of movement for over 15 minutes and when gently touched and shaking 
in place. After a mouse was euthanized, the spleen and liver were collected, homogenized, and plated onto LB agar plates at dilutions ranging from $10^{-2}-10^{-9}$ to determine the CFU/g. The blood was also taken from each mouse and serially diluted in PBS to determine the $\mathrm{CFU} / \mathrm{mL}$.

\section{Acknowledgements}

This project was partially funded by The University of Texas at Dallas Office of Research through the SPIRe grant program. J.J.G. thanks the National Science Foundation [CAREER DMR-1654405 and DMR-2003534] and the Welch Foundation [AT-1989-20190330]. N.J.D. thanks the Welch Foundation [AT-2030-20200401]. The Gassensmith Lab would like to thank the University of Texas at Dallas lab animal resource center (LARC) for mouse maintenance. We especially like to thank Tyler Tornblom and Bradly Woody from LARC for the mice training they provided. C.E.B. thanks the National Science Foundation Graduate Research Fellows Program (1746053).

\section{Author Contribution}

Primary manuscript writing and editing was done by M.A.L., M.A.I. N.J.D. and J.J.G. Cytokine ELISA, body clearance, flow cytometry, and survival challenge were done by M.A.L. SEM, EDX, Mouse injections and blood draws were done by M.A.L. and F.C.H. TEM imaging was done by O.R.B. Confocal images were taken by O.R.B. and C.E.B. Cytotoxicity assays were done by O.R.B and R.E. PXRD was done by Y.W. smURFP induction was done by K.V. Histological analysis was done by A.S, F.C.H, and J.G. Whole IgG ELISA was done by S.P and Isotype multiplex assay was done by J.G. Flow prep was done by M.A.L., A.S., and O.R.B. ZIF optimization was done by M.A.L. and F.C.H. Stabilization studies over time were done by F. C. H. Agglutination assay was conducted by T.H. and S.V. Bacteria growth and killing assay was done by F.C.H. Immunological studies were aided by M.D.B. Funding was raised by N.J.D. and J.J.G.

\section{Competing Interest}

The authors declare no competing interest. 


\section{References}

1. Chen, D.; Qian, X., A Brief History of Bacteria: The Everlasting Game Between Humans and Bacteria. World Scientific Publishing Company: Singpore, 2017; pp 80-87

2. Kabbani, M.; Kramer, M., Urinary Tract Infection (UTI). In Urology at a Glance; Merseburger, A., Kuczyk, M., Moul, J., Eds.; Springer, Berlin, Heidelberg, 2014; pp 157-160.

3. Terlizzi, M. E.; Gribaudo, G.; Maffei, M. E., UroPathogenic Escherichia Coli (UPEC) Infections: Virulence Factors, Bladder Responses, Antibiotic, and Non-Antibiotic Antimicrobial Strategies. Front. Microbiol. 2017, 8, 1566.

4. Foxman, B., Epidemiology of Urinary Tract Infections: Incidence, Morbidity, and Economic Costs. Dis. -Mon. 2003, 49, 53-70.

5. Neugent, M. L.; Hulyalkar, N. V.; Nguyen, V. H.; Zimmern, P. E.; De Nisco, N. J., Advances in Understanding the Human Urinary Microbiome and Its Potential Role in Urinary Tract Infection. mBio 2020, 11, e00218-20.

6. Neal, D. E., Jr., Complicated Urinary Tract Infections. Urol. Clin. North Am. 2008, 35, 1322.

7. Mariano, L. L.; Ingersoll, M. A., The Immune Response to Infection in the Bladder. Nat. Rev. Urol. 2020, 17, 439-458.

8. Tandan, M.; Duane, S.; Cormican, M.; Murphy, A. W.; Vellinga, A., Reconsultation and Antimicrobial Treatment of Urinary Tract Infection in Male and Female Patients in General Practice. Antibiotics 2016, 5, 31.

9. Conway, L. J.; Carter, E. J.; Larson, E. L., Risk Factors for Nosocomial Bacteremia Secondary to Urinary Catheter-Associated Bacteriuria: A Systematic Review. Urol. Nurs. 2015, 35, 191-203.

10. Majeed, A.; Alarfaj, S.; Darouiche, R.; Mohajer, M., An Update on Emerging Therapies for Urinary Tract Infections. Expert Opin. Emerging Drugs 2017, 22, 53-62.

11. Hooton, T. M., Recurrent Urinary Tract Infection in Women. Int. J. Antimicrob. Agents 2001, 17, 259-268.

12. Mellata, M.; Mitchell, N. M.; Schödel, F.; Curtiss, R. R.; Pier, G. B., Novel Vaccine Antigen Combinations Elicit Protective Immune Responses Against Escherichia Coli Sepsis. Vaccine 2016, 34, 656-662.

13. Artero, A.; Zaragoza, R.; Camarena, J. J.; Sancho, S.; Gonzalez, R.; Nogueira, J. M., Prognostic Factors of Mortality in Patients with Community-Acquired Bloodstream Infection with Severe Sepsis and Septic Shock. J. Crit. Care 2010, 25, 276-281.

14. Labelle, A.; Juang, P.; Reichley, R.; Micek, S.; Hoffmann, J.; Hoban, A.; Hampton, N.; Kollef, M., The Determinants of Hospital Mortality Among Patients with Septic Shock Receiving Appropriate Initial Antibiotic Treatment*. Crit. Care Med. 2012, 40, 2016-2021.

15. Medina, E.; Guzmán, C. A., Use of Live Bacterial Vaccine Vectors for Antigen Delivery: Potential and Limitations. Vaccine 2001, 19, 1573-1580.

16. Lin, I. Y.; Van, T. T.; Smooker, P. M., Live-Attenuated Bacterial Vectors: Tools for Vaccine and Therapeutic Agent Delivery. Vaccines 2015, 3, 940-972.

17. Weintraub, A., Immunology of Bacterial Polysaccharide Antigens. Carbohydr. Res. 2003, 338, 2539-2547.

18. Nesta, B.; Pizza, M., Vaccines Against Escherichia Coli. In Escherichia Coli, a Versatile Pathogen; Frankel, G., Ron, E., Eds.; Springer, Cham, 2018, pp 213-242.

19. Svanborg- Edén, C.; Svennerholm, A. M., Secretory Immunoglobulin A and Immunoglobulin G Antibodies Prevent Adhesion of Escherichia Coli to Human Urinary Tract Epithelial Cells. Infect. Immun. 1978, 22, 790-797. 
20. Alteri, C. J.; Hagan, E. C.; Sivick, K. E.; Smith, S. N.; Mobley, H. L., Mucosal Immunization with Iron Receptor Antigens Protects Against Urinary Tract Infection. PLoS Pathog. 2009, 5, e1000586.

21. Hayes, B. W.; Abraham, S. N.; Mulvey, M. A.; Stapleton, A. E.; Klumpp, D. J., Innate Immune Responses to Bladder Infection. Microbiol. Spectrum 2016, 4, 4-6.

22. Welch, R. A.; Burland, V.; Plunkett, G., 3rd; Redford, P.; Roesch, P.; Rasko, D.; Buckles, E. L.; Liou, S. R.; Boutin, A.; Hackett, J.; Stroud, D.; Mayhew, G. F.; Rose, D. J.; Zhou, S.; Schwartz, D. C.; Perna, N. T.; Mobley, H. L.; Donnenberg, M. S.; Blattner, F. R., Extensive Mosaic Structure Revealed by the Complete Genome Sequence of Uropathogenic Escherichia Coli. Proc. Natl. Acad. Sci. U. S. A. 2002, 99, 17020-17024.

23. Moriel, D. G.; Bertoldi, I.; Spagnuolo, A.; Marchi, S.; Rosini, R.; Nesta, B.; Pastorello, I.; Corea, V. A.; Torricelli, G.; Cartocci, E.; Savino, S.; Scarselli, M.; Dobrindt, U.; Hacker, J.; Tettelin, H.; Tallon, L. J.; Sullivan, S.; Wieler, L. H.; Ewers, C.; Pickard, D.; et al., Identification of Protective and Broadly Conserved Vaccine Antigens from the Genome of Extraintestinal Pathogenic Escherichia Coli. Proc. Natl. Acad. Sci. U. S. A. 2010, 107, 9072-9077.

24. Mobley, H. L.; Alteri, C. J., Development of a Vaccine Against Escherichia coli Urinary Tract Infections. Pathogens 2016, 5, 1.

25. Uehling, D. T.; Hopkins, W. J.; Elkahwaji, J. E.; Schmidt, D. M.; Leverson, G. E., Phase 2 Clinical Trial of a Vaginal Mucosal Vaccine for Urinary Tract Infections. J. Urol. 2003, 170, 867-869.

26. O'Brien, V. P.; Hannan, T. J.; Nielsen, H. V.; Hultgren, S. J., Drug and Vaccine Development for the Treatment and Prevention of Urinary Tract Infections. Microbiol Spectr. 2016, 4, 589-646.

27. Aziminia, N.; Hadjipavlou, M.; Philippou, Y.; Pandian, S. S.; Malde, S.; Hammadeh, M. Y., Vaccines for the Prevention of Recurrent Urinary Tract Infections: A Systematic Review. BJU Int. 2019, 123, 753-768.

28. Cryz, S. J., Jr.; Fürer, E.; Germanier, R., Effect of Chemical and Heat Inactivation on the Antigenicity and Immunogenicity of Vibrio Cholerae. Infect. Immun. 1982, 38, 21-26.

29. Langemann, T.; Koller, V. J.; Muhammad, A.; Kudela, P.; Mayr, U. B.; Lubitz, W., The Bacterial Ghost Platform System: Production and Applications. Bioeng. Bugs 2010, 1, 326-336.

30. Jones, C., Stability and Degradation Pathways of Polysaccharide and Glycoconjugate Vaccines. In Stability of complex carbohydrate structures: Biofuels, Food, Vaccines, and Shipwrecks; Harding, S. E., Eds.; Royal Society: Cambridge UK, 2012; pp 56-67.

31. Cárdenas, L.; Dasgupta, U.; Clements, J. D., Influence of Strain Viability and Antigen Dose on the Use of Attenuated Mutants of Salmonella as Vaccine Carriers. Vaccine 1994, 12, 833-840.

32. Blackburn, N. K.; Besselaar, T. G., A Study of the Effect of Chemical Inactivants on the Epitopes of Rift Valley Fever Virus Glycoproteins using Monoclonal Antibodies. J. Virol. Methods 1991, 33, 367-374.

33. Tsen, S. W. D.; Donthi, N.; La, V.; Hsieh, W. H.; Li, Y. D.; Knoff, J.; Chen, A.; Wu, T. C.; Hung, C. F.; Achilefu, S.; Tsen, K. T., Chemical-Free Inactivated Whole Influenza Virus Vaccine Prepared by Ultrashort Pulsed Laser Treatment. J. Biomed. Opt. 2015, 20, 051008.

34. Frey, J., Biological Safety Concepts of Genetically Modified Live Bacterial Vaccines. Vaccine 2007, 25, 5598-5605.

35. Tam, H. H.; Melo, M. B.; Kang, M.; Pelet, J. M.; Ruda, V. M.; Foley, M. H.; Hu, J. K.; Kumari, S.; Crampton, J.; Baldeon, A. D.; Sanders, R. W.; Moore, J. P.; Crotty, S.; Langer, R.; Anderson, D. G.; Chakraborty, A. K.; Irvine, D. J., Sustained Antigen Availability During Germinal Center Initiation Enhances Antibody Responses to Vaccination. Proc. Natl. Acad. Sci. U. S. A. 2016, 113, 6639-6648.

36. Awate, S.; Babiuk, L. A.; Mutwiri, G., Mechanisms of Action of Adjuvants. Front. Immunol. 2013, 4, 114. 
37. Luzuriaga, M. A.; Welch, R. P.; Dharmarwardana, M.; Benjamin, C. E.; Li, S.; Shahrivarkevishahi, A.; Popal, S.; Tuong, L. H.; Creswell, C. T.; Gassensmith, J. J., Enhanced Stability and Controlled Delivery of MOF-Encapsulated Vaccines and Their Immunogenic Response in Vivo. ACS Appl. Mater. Interfaces 2019, 11, 9740-9746.

38. Flores, O.; Santra, S.; Kaittanis, C.; Bassiouni, R.; Khaled, A. S.; Khaled, A. R.; Grimm, J.; Perez, J. M., PSMA-Targeted Theranostic Nanocarrier for Prostate Cancer. Theranostics 2017, 7, 2477-2494.

39. Mitra, A.; Coleman, T.; Borgman, M.; Nan, A.; Ghandehari, H.; Line, B. R., Polymeric Conjugates of Mono- and Bi-Cyclic AlphaVbeta3 Binding Peptides for Tumor Targeting. J. Controlled Release 2006, 114, 175-83.

40. Chen, N.; Gallovic, M. D.; Tiet, P.; Ting, J. P. Y.; Ainslie, K. M.; Bachelder, E. M., Investigation of Tunable Acetalated Dextran Microparticle Platform to Optimize M2e-Based Influenza Vaccine Efficacy. J. Controlled Release 2018, 289, 114-124.

41. Chen, N.; Johnson, M. M.; Collier, M. A.; Gallovic, M. D.; Bachelder, E. M.; Ainslie, K. M., Tunable Degradation of Acetalated Dextran Microparticles Enables Controlled Vaccine Adjuvant and Antigen Delivery to Modulate Adaptive Immune Responses. J. Controlled Release 2018, 273, 147-159.

42. Gallovic, M. D.; Montjoy, D. G.; Collier, M. A.; Do, C.; Wyslouzil, B. E.; Bachelder, E. M.; Ainslie, K. M., Chemically Modified Inulin Microparticles Serving Dual Function as a Protein Antigen Delivery Vehicle and Immunostimulatory Adjuvant. Biomater Sci. 2016, 4, 483-493.

43. Frizzell, H.; Ohlsen, T. J.; Woodrow, K. A., Protein-Loaded Emulsion Electrospun Fibers Optimized for Bioactivity Retention and $\mathrm{pH}$-Controlled Release for Peroral Delivery of Biologic Therapeutics. Int J Pharm. 2017, 533, 99-110.

44. Klegerman, M. E.; Naji, A. K.; Haworth, K. J.; Zou, Y.; Golunski, E.; Peng, T.; Britton, G. L.; Huang, S. L.; Holland, C. K.; McPherson, D. D., Ultrasound-Enhanced Bevacizumab Release from Echogenic Liposomes for Inhibition of Atheroma Progression. J. Liposome Res. 2016, 26, 47-56.

45. Dasgupta, I.; Tanifum, E. A.; Srivastava, M.; Phatak, S. S.; Cavasotto, C. N.; Analoui, M.; Annapragada, A., Non Inflammatory Boronate Based Glucose-Responsive Insulin Delivery Systems. PLoS One. 2012, 7, e29585.

46. Karathanasis, E.; Bhavane, R.; Annapragada, A. V., Glucose-Sensing Pulmonary Delivery of hHuman Insulin to the Systemic Circulation of Rats. Int. J. Nanomedicine 2007, 2, 501-13.

47. Joanitti, G. A.; Sawant, R. S.; Torchilin, V. P.; Freitas, S. M.; Azevedo, R. B., Optimizing liposomes for Delivery of Bowman-Birk Protease Inhibitors - Platforms for Multiple Biomedical Applications. Colloids Surf., B 2018, 167, 474-482.

48. Martinez, A. P.; Qamar, B.; Fuerst, T. R.; Muro, S.; Andrianov, A. K., Biodegradable "Smart" Polyphosphazenes with Intrinsic Multifunctionality as Intracellular Protein Delivery Vehicles. Biomacromolecules 2017, 18, 2000-2011.

49. Martinez, A. P.; Qamar, B.; Marin, A.; Fuerst, T. R.; Muro, S.; Andrianov, A. K., Biodegradable "Scaffold" Polyphosphazenes for Non-Covalent PEGylation of Proteins. ACS Symp. Ser. 2018,1298,121-141.

50. Gu, L.; Ruff, L. E.; Qin, Z.; Corr, M.; Hedrick, S. M.; Sailor, M. J., Multivalent Porous Silicon Nanoparticles Enhance the Immune Activation Potency of Agonistic CD40 Antibody. Adv. Mater. 2012, 24, 3981-3987.

51. Wu, C. C.; Hu, Y.; Miller, M.; Aroian, R. V.; Sailor, M. J., Protection and Delivery of Anthelmintic Protein Cry5B to Nematodes Using Mesoporous Silicon Particles. ACS Nano 2015, 9, 6158-6167.

52. Zuidema, J. M.; Kumeria, T.; Kim, D.; Kang, J.; Wang, J.; Hollett, G.; Zhang, X.; Roberts, D. S.; Chan, N.; Dowling, C.; Blanco-Suarez, E.; Allen, N. J.; Tuszynski, M. H.; Sailor, M. J., 
Oriented Nanofibrous Polymer Scaffolds Containing Protein-Loaded Porous Silicon Generated by Spray Nebulization. Adv. Mater. 2018, 30, e1706785.

53. DeLouise, L. A.; Kou, P. M.; Miller, B. L., Cross-Correlation of Optical Microcavity Biosensor Response with Immobilized Enzyme Activity. Insights into Biosensor Sensitivity. Anal. Chem. 2005, 77, 3222-3230.

54. Wang, W.; Lee, C.; Pastuszka, M.; Laurie, G. W.; MacKay, J. A., Thermally-Responsive Loading and Release of Elastin-Like Polypeptides from Contact Lenses. Pharmaceutics 2019, $11,221$.

55. Dhandhukia, J. P.; Brill, D. A.; Kouhi, A.; Pastuszka, M. K.; MacKay, J. A., Elastin-Like Polypeptide Switches: A Design Strategy to Detect Multimeric Proteins. Protein Sci. 2017, 26, 1785-1795.

56. Wen, A. M.; Shukla, S.; Saxena, P.; Aljabali, A. A.; Yildiz, I.; Dey, S.; Mealy, J. E.; Yang, A. C.; Evans, D. J.; Lomonossoff, G. P.; Steinmetz, N. F., Interior Engineering of a Viral Nanoparticle and Its Tumor Homing Properties. Biomacromolecules. 2012, 13, 3990-4001.

57. Morales, D. P.; Braun, G. B.; Pallaoro, A.; Chen, R.; Huang, X.; Zasadzinski, J. A.; Reich, N. O., Targeted Intracellular Delivery of Proteins with Spatial and Temporal Control. Mol. Pharm. 2015, 12, 600-609.

58. Golan-Paz, S.; Frizzell, H.; Woodrow, K. A., Cross-Platform Comparison of Therapeutic Delivery from Multilamellar Lipid-Coated Polymer Nanoparticles. Macromol. Biosci. 2019, 19, e1800362.

59. Al-Handawi, M. B.; Commins, P.; Shukla, S.; Didier, P.; Tanaka, M.; Raj, G.; Veliz, F. A.; Pasricha, R.; Steinmetz, N. F.; Naumov, P., Encapsulation of Plant Viral Particles in Calcite Crystals. Adv. Biosyst. 2018, 2, e1700176.

60. Lee, P. W.; Shukla, S.; Wallat, J. D.; Danda, C.; Steinmetz, N. F.; Maia, J.; Pokorski, J. K., Biodegradable Viral Nanoparticle/Polymer Implants Prepared via Melt-Processing. ACS Nano 2017, 11, 8777-8789.

61. Xu, A.-W.; Ma, Y.; Cölfen, H., Biomimetic Mineralization. J. Mater. Chem. 2007, 17, 415449.

62. Liang, K.; Ricco, R.; Doherty, C. M.; Styles, M. J.; Bell, S.; Kirby, N.; Mudie, S.; Haylock, D.; Hill, A. J.; Doonan, C. J.; Falcaro, P., Biomimetic Mineralization of Metal-Organic Frameworks as Protective Coatings for Biomacromolecules. Nat. Commun. 2015, 6, 7240.

63. Park, K. S.; Ni, Z.; Cote, A. P.; Choi, J. Y.; Huang, R.; Uribe-Romo, F. J.; Chae, H. K.; O'Keeffe, M.; Yaghi, O. M., Exceptional Chemical and Thermal Stability of Zeolitic Imidazolate Frameworks. Proc. Natl. Acad. Sci. U. S. A. 2006, 103, 10186-10191.

64. Luzuriaga, M. A.; Benjamin, C. E.; Gaertner, M. W.; Lee, H.; Herbert, F. C.; Mallick, S.; Gassensmith, J. J., ZIF-8 Degrades in Cell Media, Serum, and Some-But Not All-Common Laboratory Buffers. Supramol. Chem. 2019, 31, 485-490.

65. Wang, C.; Sudlow, G.; Wang, Z.; Cao, S.; Jiang, Q.; Neiner, A.; Morrissey, J. J.; Kharasch, E. D.; Achilefu, S.; Singamaneni, S., Metal-Organic Framework Encapsulation Preserves the Bioactivity of Protein Therapeutics. Adv. Healthc. Mater. 2018, 7, e1800950.

66. Wang, C.; Sun, H.; Luan, J.; Jiang, Q.; Tadepalli, S.; Morrissey, J. J.; Kharasch, E. D.; Singamaneni, S., Metal-Organic Framework Encapsulation for Biospecimen Preservation. Chem. Mater. 2018, 30, 1291-1300.

67. Zhang, Y.; Wang, F.; Ju, E.; Liu, Z.; Chen, Z.; Ren, J.; Qu, X.,

Metal-Organic-Framework-Based Vaccine Platforms for Enhanced Systemic Immune and Memory Response. Adv. Funct. Mater. 2016, 26, 6454-6461.

68. Wang, C.; Tadepalli, S.; Luan, J.; Liu, K. K.; Morrissey, J. J.; Kharasch, E. D.; Naik, R. R.; Singamaneni, S., Metal-Organic Framework as a Protective Coating for Biodiagnostic Chips. Adv. Mater. 2017, 29, 1604433. 
69. Li, P.; Moon, S.-Y.; Guelta, M. A.; Harvey, S. P.; Hupp, J. T.; Farha, O. K., Encapsulation of a Nerve Agent Detoxifying Enzyme by a Mesoporous Zirconium Metal-Organic Framework Engenders Thermal and Long-Term Stability. J. Am. Chem. Soc. 2016, 138, 8052-8055.

70. Li, S.; Dharmarwardana, M.; Welch, R. P.; Benjamin, C. E.; Shamir, A. M.; Nielsen, S. O.; Gassensmith, J. J., Investigation of Controlled Growth of Metal-Organic Frameworks on Anisotropic Virus Particles. ACS Appl. Mater. Interfaces 2018, 10, 18161-18169.

71. Liang, K.; Richardson, J. J.; Cui, J.; Caruso, F.; Doonan, C. J.; Falcaro, P., MetalOrganic Framework Coatings as Cytoprotective Exoskeletons for Living Cells. Adv. Mater. 2016, 28, 7910-7914.

72. Ricco, R.; Liang, W.; Li, S.; Gassensmith, J. J.; Caruso, F.; Doonan, C.; Falcaro, P., Metal-Organic Frameworks for Cell and Virus Biology: A Perspective. ACS Nano. 2018, 12, 1323.

73. Herbert, F. C.; Abeyrathna, S.; Abeyrathna, N.; Wijesundara, Y.; Brohlin, O.; Luzuriaga, M. A.; Durand-Silva, A.; Diwakara, S. D.; Smaldone, R. A.; Meloni, G.; Gassensmith, J. J., Stabilization of Supramolecular Membrane Protein-Lipid Bilayer Assemblies through Immobilization in a Crystalline Exoskeleton. Nat. Commun. 2021, 12, 2202.

74. Li, S.; Zhou, X.; Chen, Z.; Herbert, F. C.; Jayawickramage, R.; Panangala, S. D.; Luzuriaga, M. A.; Alahakoon, S. B.; Diwakara, S. D.; Meng, X.; Fei, L.; Ferraris, J.; Smaldone, R. A.; Gassensmith, J. J., Hierarchical Porous Carbon Arising from Metal-Organic FrameworkEncapsulated Bacteria and Its Energy Storage Potential. ACS Appl. Mater. Interfaces 2020, 12, 11884-11889.

75. Falcaro, P.; Ricco, R.; Doherty, C. M.; Liang, K.; Hill, A. J.; Styles, M. J., MOF Positioning Technology and Device Fabrication. Chem. Soc. Rev. 2014, 43, 5513-5560.

76. Vasconcelos, I. B.; Silva, T. G. d.; Militão, G. C. G.; Soares, T. A.; Rodrigues, N. M.; Rodrigues, M. O.; Costa, N. B. d.; Freire, R. O.; Junior, S. A., Cytotoxicity and Slow Release of the Anti-Cancer Drug Doxorubicin from ZIF-8. RSC Adv. 2012, 2, 9437-9442.

77. Kaper, J. B.; Nataro, J. P.; Mobley, H. L., Pathogenic Escherichia coli. Nat. Rev. Microbiol. 2004, 2, 123-140.

78. Spurbeck, R. R.; Stapleton, A. E.; Johnson, J. R.; Walk, S. T.; Hooton, T. M.; Mobley, H. L., Fimbrial Profiles Predict Virulence of Uropathogenic Escherichia Coli Strains: Contribution of Ygi and Yad Fimbriae. Infect. Immun. 2011, 79, 4753-4763.

79. Jalava, K., Bacterial Ghosts as Vaccine Candidates for Veterinary Applications. J. Controlled Release 2002, 85, 17-25.

80. Torres, J. F.; Lyerly, D. M.; Hill, J. E.; Monath, T. P., Evaluation of Formalin-Inactivated Clostridium Difficile Vaccines Administered by Parenteral and Mucosal Routes of Immunization in Hamsters. Infect. Immun. 1995, 63, 4619-4627.

81. Sunwoo, H. H.; Lee, E. N.; Menninen, K.; Suresh, M. R.; Sim, J. S., Growth Inhibitory Effect of Chicken Egg Yolk Antibody (IgY) on Escherichia Coli O157:H7. J. Food Sci. 2002, 67, 1486-1494.

82. Counago, R. M.; Ween, M. P.; Begg, S. L.; Bajaj, M.; Zuegg, J.; O'Mara, M. L.; Cooper, M. A.; McEwan, A. G.; Paton, J. C.; Kobe, B.; McDevitt, C. A., Imperfect Coordination Chemistry Facilitates Metal lon Release in the Psa Permease. Nat. Chem. Biol. 2014, 10, 35-41.

83. Velasco, E.; Wang, S.; Sanet, M.; Fernandez-Vazquez, J.; Jove, D.; Glaria, E.; Valledor, A. F.; O'Halloran, T. V.; Balsalobre, C., A New Role for Zinc Limitation in Bacterial Pathogenicity: Modulation of Alpha-Hemolysin from Uropathogenic Escherichia Coli. Sci. Rep. 2018, 8, 6535.

84. McDevitt, C. A.; Ogunniyi, A. D.; Valkov, E.; Lawrence, M. C.; Kobe, B.; McEwan, A. G.; Paton, J. C., A Molecular Mechanism for Bacterial Susceptibility to Zinc. PLoS Pathog. 2011, 7, e1002357.

85. Pape, K. A.; Catron, D. M.; Itano, A. A.; Jenkins, M. K., The Humoral Immune Response is Initiated in Lymph Nodes by B Cells that Acquire Soluble Antigen Directly in the Follicles. Immunity 2007, 26, 491-502. 
86. Zhang, N. Z.; Xu, Y.; Wang, M.; Chen, J.; Huang, S. Y.; Gao, Q.; Zhu, X. Q., Vaccination with Toxoplasma Gondii Calcium-Dependent Protein Kinase 6 and Rhoptry Protein 18 Encapsulated in Poly(Lactide-Co-Glycolide) Microspheres Induces Long-Term Protective Immunity in Mice. BMC Infect. Dis. 2016, 16, 168.

87. Campos, I. B.; Herd, M.; Moffitt, K. L.; Lu, Y. J.; Darrieux, M.; Malley, R.; Leite, L. C.; Gonçalves, V. M., IL-17A and Complement Contribute to Killing of Pneumococci Following Immunization with a Pneumococcal Whole Cell Vaccine. Vaccine. 2017, 35, 1306-1315.

88. Herbert, F. C.; Brohlin, O. R.; Galbraith, T.; Benjamin, C.; Reyes, C. A.; Luzuriaga, M. A.; Shahrivarkevishahi, A.; Gassensmith, J. J., Supramolecular Encapsulation of Small-Ultrared Fluorescent Proteins in Virus-Like Nanoparticles for Noninvasive in Vivo Imaging Agents. Bioconjugate Chem. 2020, 31, 1529-1536.

89. Welch, R. P.; Lee, H.; Luzuriaga, M. A.; Brohlin, O. R.; Gassensmith, J. J., ProteinPolymer Delivery: Chemistry from the Cold Chain to the Clinic. Bioconjugate Chem. 2018, 29, 2867-2883.

90. Tanaka, T.; Narazaki, M.; Kishimoto, T., IL-6 in Inflammation, Immunity, and Disease. Cold Spring Harb. Perspect. Biol. 2014, 6, a016295.

91. Hoop, M.; Walde, C. F.; Riccò, R.; Mushtaq, F.; Terzopoulou, A.; Chen, X.-Z.; demello, A. J.; Doonan, C. J.; Falcaro, P.; Nelson, B. J.; Puigmartí-Luis, J.; Pané, S., Biocompatibility Characteristics of the Metal Organic Framework ZIF-8 for Therapeutical Applications. Appl. Mater. Today 2018, 11, 13-21.

92. Li, S.; Wang, K.; Shi, Y.; Cui, Y.; Chen, B.; He, B.; Dai, W.; Zhang, H.; Wang, X.; Zhong, C.; Wu, H.; Yang, Q.; Zhang, Q., Novel Biological Functions of ZIF-NP as a Delivery Vehicle: High Pulmonary Accumulation, Favorable Biocompatibility, and Improved Therapeutic Outcome. Adv. Funct. Mater. 2016, 26, 2715-2727.

93. Boopathy, A. V.; Mandal, A.; Kulp, D. W.; Menis, S.; Bennett, N. R.; Watkins, H. C.; Wang, W.; Martin, J. T.; Thai, N. T.; He, Y.; Schief, W. R.; Hammond, P. T.; Irvine, D. J., Enhancing Humoral Immunity via Sustained-Release Implantable Microneedle Patch Vaccination. Proc. Natl. Acad. Sci. U. S. A. 2019, 116, 16473-16478.

94. Silva, A. L.; Soema, P. C.; Slütter, B.; Ossendorp, F.; Jiskoot, W., PLGA Particulate Delivery Systems for Subunit Vaccines: Linking Particle Properties to Immunogenicity. Hum. Vaccin. Immunother. 2016, 12, 1056-1069.

95. Roth, G. A.; Gale, E. C.; Alcántara-Hernández, M.; Luo, W.; Axpe, E.; Verma, R.; Yin, Q.; Yu, A. C.; Lopez Hernandez, H.; Maikawa, C. L.; Smith, A. A. A.; Davis, M. M.; Pulendran, B.; Idoyaga, J.; Appel, E. A., Injectable Hydrogels for Sustained Codelivery of Subunit Vaccines Enhance Humoral Immunity. ACS Cent. Sci. 2020, 6, 1800-1812.

96. Chen, T. T.; Yi, J. T.; Zhao, Y. Y.; Chu, X., Biomineralized Metal-Organic Framework Nanoparticles Enable Intracellular Delivery and Endo-Lysosomal Release of Native Active Proteins. J. Am. Chem. Soc. 2018, 140, 9912-9920.

97. Sun, C. Y.; Qin, C.; Wang, X. L.; Yang, G. S.; Shao, K. Z.; Lan, Y. Q.; Su, Z. M.; Huang, P.; Wang, C. G.; Wang, E. B., Zeolitic Imidazolate Framework-8 as Efficient pH-Sensitive Drug Delivery Vehicle. Dalton Trans. 2012, 41, 6906-6909.

98. Durymanov, M.; Permyakova, A.; Sene, S.; Guo, A.; Kroll, C.; Giménez-Marqués, M.; Serre, C.; Reineke, J., Cellular Uptake, Intracellular Trafficking, and Stability of Biocompatible Metal-Organic Framework (MOF) Particles in Kupffer Cells. Mol. Pharm. 2019, 16, 2315-2325.

99. Zhong, X.; Zhang, Y.; Tan, L.; Zheng, T.; Hou, Y.; Hong, X.; Du, G.; Chen, X.; Zhang, Y.; Sun, $X$., An Aluminum Adjuvant-Integrated Nano-MOF as Antigen Delivery System to Induce Strong Humoral and Cellular Immune Responses. J. Controlled Release 2019, 300, 81-92.

100. Galeotti, C.; Karnam, A.; Das, M.; Kaveri, S. V.; Bayry, J., Acid Stripping of Surface IgE Antibodies Bound to FceRI Is Unsuitable for the Functional Assays That Require Long-Term Culture of Basophils and Entire Removal of Surface IgE. Int. J. Mol. Sci. 2020, 21, 510. 
101. Greer, A. M.; Wu, N.; Putnam, A. L.; Woodruff, P. G.; Wolters, P.; Kinet, J. P.; Shin, J. S., Serum IgE Clearance is Facilitated by Human FcERI Internalization. J. Clin. Invest. 2014, 124, 1187-1198.

102. Kameyama, S.; Horie, M.; Kikuchi, T.; Omura, T.; Tadokoro, A.; Takeuchi, T.; Nakase, I.; Sugiura, Y.; Futaki, S., Acid Wash in Determining Cellular Uptake of Fab/cell-Permeating Peptide Conjugates. Biopolymers 2007, 88, 98-107.

103. Obst, R.; van Santen, H. M.; Melamed, R.; Kamphorst, A. O.; Benoist, C.; Mathis, D., Sustained Antigen Presentation Can Promote an Immunogenic T cell Response, like Dendritic Cell Activation. Proc. Natl. Acad. Sci. U. S. A. 2007, 104, 15460-15465.

104. Demento, S. L.; Cui, W.; Criscione, J. M.; Stern, E.; Tulipan, J.; Kaech, S. M.; Fahmy, T. M., Role of Sustained Antigen Release from Nanoparticle Vaccines in Shaping the $T$ Cell Memory Phenotype. Biomaterials 2012, 33, 4957-4964.

105. Spellberg, B.; Edwards, J. E., Jr., Type 1/Type 2 Immunity in Infectious Diseases. Clin. Infect. Dis. 2001, 32, 76-102.

106. Natarajan, K.; Jiang, J.; May, N. A.; Mage, M. G.; Boyd, L. F.; McShan, A. C.; Sgourakis, N. G.; Bax, A.; Margulies, D. H., The Role of Molecular Flexibility in Antigen Presentation and T Cell Receptor-Mediated Signaling. Front. Immunol. 2018, 9, 1657.

107. Zychlinsky Scharff, A.; Rousseau, M.; Lacerda Mariano, L.; Canton, T.; Consiglio, C. R.; Albert, M. L.; Fontes, M.; Duffy, D.; Ingersoll, M. A., Sex Differences in IL-17 Contribute to Chronicity in Male Versus Female Urinary Tract Infection. JCI Insight 2019, 4, e122998.

108. Sivick, K. E.; Schaller, M. A.; Smith, S. N.; Mobley, H. L. T., The Innate Immune Response to Uropathogenic Escherichia Coli Involves IL-17A in a Murine Model of Urinary Tract Infection. J. Immunol. 2010, 184, 2065-2075.

109. Chamoun, M. N.; Sullivan, M. J.; Goh, K. G. K.; Acharya, D.; Ipe, D. S.; Katupitiya, L.; Gosling, D.; Peters, K. M.; Sweet, M. J.; Sester, D. P.; Schembri, M. A.; Ulett, G. C., Restriction of Chronic Escherichia Coli Urinary Tract Infection Depends upon T Cell-Derived Interleukin-17, a Deficiency of Which Predisposes to Flagella-Driven Bacterial Persistence. FASEB J. 2020, 34, $14572-14587$.

110. Smith, S. N.; Hagan, E. C.; Lane, M. C.; Mobley, H. L. T., Dissemination and Systemic Colonization of Uropathogenic Escherichia Coli in a Murine Model of Bacteremia. mBio 2010, 1, e00262-10.

111. Carraro, F.; William, J. D.; Linares-Moreau, M.; Parise, C.; Liang, W.; Amenitsch, H. Doonan, C.; Kappe, C. O.; Falcaro, P., Continuous-Flow Synthesis of ZIF-8 Biocomposites with Tunable Particle Size. Angew. Chem. 2020, 59, 8123-8127. 